\title{
KAJIAN REVITALISASI PASAR PLERET KABUPATEN BANTUL
}

\author{
Drs. Prihatno, M'M' \\ Dosen Sekolah Tinggi Pariwisata AMPTA Yogyakarta \\ NIDN : 0526125901
}

\begin{abstract}
The existence of traditional markets that have unique functions and diversity must be preserved and conserved as one characteristic of the culture in the district of Bantul in particular because there are values that are not contained in a modern shopping center. This has encouraged the government is obliged to immediately revitalize traditional markets in order to respond to the chronic problems of the traditional market which is related to the traditional market image problem. Traditional markets imaged as a rundown, dirty, muddy, poorly maintained, and has a quality level of occupancy very rendah.Program traditional market revitalization aims to improve the performance and quality of the market

Review activity Market Revitalization Pleret intended to identify the physical, economic, management, environmental and social, in order to obtain data that can be used to find out the problems and constraints faced by market Pleret development efforts as a traditional market better, formulate. Market revitalization programs and activities Pleret Bantul and provide recommendations on structuring the physical aspects, economics, management, socio-cultural environment and Pleret Pasar Bantul.

The results showed that Pleret Market is a traditional market with pancawara or use the 'market'. namely a market which used 'pasara' which consisted of five days a week, namely PON', Legi, Pahing, Pon and Wage. And the market Pleret uses only two days is the day with the 'market' Pon and day with the 'market' PON' while other days by Legi, Pahing and Wage in the market Pleret not move alias lid so that the count of time efficiency, the market Pleret including market inefficient because only open 12 days a month.

In an effort to improve the image and power saing Pasar Pleret, it is recommended that the market Pleret can soon turn into a normal market, business should immediately take the policy with regard to improving the management of Market Pleret, so that this market can operate optimally and efficiently, serve the needs of society, merchants increase revenue, and increase revenue (PAD) through retribution market which will eventually boost economic growth Bantul.
\end{abstract}

Keywords: Tradisional Markets and Revitalization

\section{PENDAHULUAN}

Sektor perdagangan merupakan industri yang strategis dan memiliki kontribusi yang besar terhadap perekonomian Kabupaten Bantul. Selain itu, sektor perdagangan juga memiliki peran yang sangat penting bagi perekonomian karena menyerap banyak tenaga kerja. Hal ini mengindikasikan bahwa banyak orang menggantungkan hidupnya pada sektor perdagangan. Dalam perkembangannya justru pedagang-pedagang kecil ini yang mendominasi jumlah tenaga kerja dalam sektor perdagangan di Kabupaten Bantul. Pedagang-pedagang ini menjelma menjadi pedagang pasar tradisional, pedagang toko 
kelontong bahkan masuk industri informal yaitu Pedagang Kaki Lima (PKL).

Eksistensi pusat perbelanjaan modern seperti minimarket, supermarket hingga hipermarket sedikit mengusik keberadaan pasar tradisional. Kesamaan fungsi yang dimiliki oleh pusat perbelanjaan modern dan pasar tradisional, telah menimbulkan persaingan antara keduanya. Menjamurnya pusat perbelanjaan modern dikhawatirkan akan mematikan keberadaan pasar tradisional yang merupakan refleksi dari ekonomi kerakyatan. Menurut Ayuningsasi (2010) dalam Siti Nurjanah (2016) bahwa pasar tradisional memiliki berbagai kelemahan yang telah menjadi karakter dasar yang sangat sulit diubah, mulai dari faktor desain, tata ruang, tataletak, dan tampilan yang tidak sebaik pusat perbelanjaan modern, alokasi waktu operasional yang relatif terbatas, kurangnya teknologi yang digunakan, kualitas barang yang kurang baik, kurangnya promosi penjualan, rendahnya tingkat keamanan, kesemrawutan parkir, hingga berbagai isu yang merusak citra pasar tradisional seperti maraknya informasi produk barang yang menggunakan zat kimia berbahaya, praktek penjualan daging oplosan, serta kecurangan-kecurangan lain dalam aktivitas penjualan dan perdagangan. Bisa jadi karena kompleksitas kelemahan pasar tradisional tersebut menyebabkan konsumen beralih dari pasar tradisional ke pusat perbelanjaan modern. (Ayuningsasi, 2010)

Namun disisi lain, Pasar tradisional memiliki keunggulan yang tidak dimiliki oleh pusat perbelanjaan modern yaitu adanya sistem tawar menawar yang menunjukkan keakraban antara penjual dan pembeli. Di pasar tradisional terdapat suatu komunikasi yang tidak akan ditemui di pusat perbelanjaan modern. Sistem tawar menawar dalam transaksi jual beli di pasar tradisional membuat suatu hubungan tersendiri antar penjual dan pembeli. Berbeda dengan pusat perbelanjaan modern dimana harga barang sudah ditetapkan dan tidak ada komunikasi antara penjual dan pembeli.Pasar tradisional memiliki keunikan yang tidak dimiliki oleh pusat perbelanjaan modern.Keberadaan pasar tradisional harus dipertahankan dan dilestarikan karena terdapat nilai-nilai yang tidak terdapat pada pusat perbelanjaan modern, keberadaan pasar tradisional harus diberdayakan agar beroperasi secara optimal dan efisien.

Keberadaan pasar tradisional yang mempunyai keaneka ragaman fungsi dan keunikan harus dipertahankan dan dilestarikan sebagai salah satu ciri khas budaya di Kabupaten Bantul khususnya karena terdapat nilai-nilai yang tidak terdapat pada pusat perbelanjaan modern. Hal inilah yang mendorong pemerintah berkewajiban untuk segera melakukan revitalisasi pasar tradisional guna merespon permasalahan menahun dari pasar tradisional yakni terkait masalah pencitraan pasar tradisional. Pasar tradisional dicitrakan sebagai suatu tempat yang kumuh, kotor, becek, tidak terawat, dan mempunyai tingkat kualitas hunian yang sangat rendah.Program revitalisasi pasar tradisional bertujuan untuk meningkatkan kinerja dan kualitas pasar.

Pasar Pleret merupakan salah satu pasar tradisional yang cukup ramai di Kabupaten Bantul, terletak di lokasi strategis yakni di Dusun Kauman, Desa Pleret, Kecamatan Pleret. Pasar ini masuk kategori kelas II dengan luas tanah \pm 6.150 $m^{2}$ dan merupakan tanah Pemerintah Daerah Negara. Pasar ini dilengkapi dengan fasilitas tempat parkir, tempat ibadah, kantor pengelola, KM/WC,sarana 
pengelolaan kebersihan, sarana pengamanan, sarana air bersih, instalasi listrik, penerangan umum. Kondisi terkini menunjukkan bahwa Pasar Pleret belum dikelola secara optimal yang disebabkan oleh permasalahan penataan tempat, kualitas SDM Pengelola, maupun promosi sehingga daya saingnya belum optimal, dan inilah yang perlu ditingkatkan dan harus dilakukan perubahan mendasar dalam pengelolaannya terutama efisiensi penggunaan waktu buka pasar.

Pasar pleret merupakan pasar tradisional dengan Pancawara atau menggunakan 'pasaran'. yakni sebuah pasar yang menggunakan'pasaran' yang terdiri dari lima hari dalam sepekan yaitu Kliwon, Legi, Pahing, Pon dan Wage. Dan pasar Pleret hanya menggunakan dua hari saja yaitu hari dengan 'pasaran' Pon dan hari dengan 'pasaran' Kliwon sedangkan hari lain dengan pasaran Legi, Pahing dan Wage di pasar pleret tidak beraktivitas alias tutup sehingga kalau dilakukan penghitungan efisiensi waktu maka pasar pleret termasuk pasar yang tidak efisien karena hanya buka 12 hari dalam sebulan.

Dalam upaya untuk meningkatkan citra dan daya saing Pasar Pleret, maka pasar pleret secara perlahan sebaiknya bisa berubah menjadi pasar normal, oleh karenanya sangat penting dilakukan kajian revitalisasi pasar tersebut. Kegiatan ini diharapkan dapat memberikan masukan terhadap kebijakan yang berkaitan dengan upaya peningkatan pengelolaan Pasar Pleret, sehingga pasar ini dapat beroperasi secara optimal dan efisien, melayani kebutuhan masyarakat, meningkatkan pendapatan pedagang, serta meningkatkan Pendapatan Asli Daerah (PAD) melalui penerimaan retribusi pasar yang pada akhirnya akan meningkatkan pertumbuhan ekonomi Kabupaten Bantul.
Kegiatan Kajian Revitalisasi Pasar Pleret dimaksudkan untuk melakukan identifikasi terhadap kondisi fisik, ekonomi, manajemen, lingkungan dan sosial budaya Pasar Pleret, sehingga diperoleh data-data yang dapat digunakan untuk mengetahui permasalahan dan kendala yang dihadapi oleh Pasar Pleret dalam upaya pengembangan sebagai pasar tradisional yang lebih baik, merumuskan program dan kegiatan revitalisasi Pasar Pleret Kabupaten Bantul dan memberikan rekomendasi terhadap penataan aspek fisik, ekonomi, manajemen, lingkungandan sosial budaya Pasar Pleret Kabupaten Bantul.

\section{LITERATUR REVIEW}

Secara umum pasar adalah tempat bertemunya penjual dengan pembeli. Pasar juga merupakan area tempat jual beli barang dengan jumlah penjual lebih dari satu, baik yang disebut sebagai pusat perbelanjaan, pasar tradisional, pertokoan, mall, palza, pusat perdagangan maupun sebutan lain.

Pasar tradisional adalah salah satu komponen utama pembentukan komunitas masyarakat baik di desa maupun di kota sebagai lembaga distribusi berbagai macam kebutuhan manusia seperti makanan, sumber energi, dan sumberdaya lainnya. Pasar berperan pula sebagai penghubung antara desa dan kota, perkembangan penduduk dan kebudayaan selalu diikuti oleh perkembangan pasar sebagai salah satu pendukung penting bagi kehidupan manusia sehari-hari terutama di kawasan perkotaan.

Pasar dapat didefinisikan sebagai institusi atau mekanisme di mana pembeli (yang membutuhkan) dan penjual (yang memproduksi) bertemu dan secara bersama-sama mengadakan pertukaran barang dan jasa (Campbell, 1990). Sedangkan menurut Stanton (2006) pasar 
adalah sebagai orang-orang yang mempunyai kebutuhan untuk dipuaskan, mempunyai uang untuk dibelanjakan dan kemauan untuk membelanjakan uang.

Dalam Peraturan Menteri

Perdagangan Nomor 70 Tahun 2013 tentang Pedoman Penataan Pasar Tradisional, Pusat Perbelanjaan dan Toko Modern, Pasar didefinisikan sebagai area tempat jual beli barang dengan jumlah penjual lebih dari satu baik yang disebut sebagai Pusat Perbelanjaan, Pasar Tradisional, Pertokoan, Mall, Plasa, Pusat Perdagangan maupun sebutan lainnya.

Pasar merupakan ruang sosial di samping ruang ekonomi. Faktor yang menyebabkan pasar tradisional masih tetap diminati adalah karakter/budaya konsumen. Meskipun informasi tentang gaya hidup modern dengan mudah diperoleh, tetapi tampaknya masyarakat masih memiliki budaya untuk tetap berkunjung dan berbelanja ke pasar tradisional. Terdapat perbedaan yang sangat mendasar antara pasar tradisional dan pasar modern. Perbedaan itulah adalah di pasar masih terjadi proses tawar-menawar harga, sedangkan di pasar modern harga sudah pasti ditandai dengan label harga. Dalam proses tawar-menawar terjalin kedekatan personal dan emosional antara penjual dan pembeli yang tidak mungkin didapatkan ketika berbelanja di pasar modern (Mukhlas, 2007).

Berdasarkan pola manajemen yang dipakai, pasar dapat dibedakan menjadi dua kelompok besar yaitu:Pasar Tradisional, adalah pasar yang masih memakai pola manajemen yang sangat sederhana dengan ciri-cirinya setiap pedagang mempunyai satu jenis usaha, adanya interaksi antara penjual dan pembeli (tawar menawar harga), penempatan barang dijajar kurang tertata rapi, kenyamanan dan keamanan kurang diperhatikan.

Pasar Modern, adalah pasar yang sudah memakai pola-pola manajemen modern, dengan ciri-ciri jenis barang dagangan yang dilakukan oleh satu pedagang, harga fixed (tetap), tata letak barang dagangan teratur dengan baik dan rapi, kenyamanan dan keamanan sudah menjadi prioritas utama.

Persamaan fungsi yang dimiliki oleh pusat perbelanjaan modern dan pasar tradisional menimbulkan persaingan antara keduanya dan juga menimbulkan modernisasi dari pasar tradisional ke pusat perbelanjaan modern.Preferensi prioritas faktor internal, faktor eksternal, faktor bertahan, dan daya tarik pusat perbelanjaan modern menyebabkan pasar tradisional mengalami kondisi bertahan, kehancuran, maupun modernisasi.Ketiganya ini dapat menyebabkan sebuah pasar tradisional dapat tetap mempertahankan konsep dan fisik bangunannya sebagai pasar, modernisasi dari pasar tradisional ke pusat perbelanjaan modern, danmenyebabkan suatu pasar tradisional ke arah kehancuran (Andreas Y.C. dan Marinus W., 2006).

Menurut Kuncoro, 2008 (dalam www.staf,uny.ac.id), isu utama yang berkaitan dengan perkembangan pasar tradisional adalah sebagai berikut (i) Jarak antara pasar tradisional dengan hypermarket yang saling berdekatan (ii) Tumbuh pesatnya minimarket (yang dimiliki pengelola jaringan) ke wilayah pemukiman (iii) Penerapan berbagai macam syarat perdagangan oleh ritel modern yang memberatkan pemasok barang (iv) Kondisi pasar tradisional secara fisik sangat tertinggal, maka perlu ada program kebijakan untuk melakukan pengaturan. 
Untuk mengatasi berbagai permasalahan tersebut, dikembangkan berbagai upaya untuk mengembangkan pasar tradisional. Salah satunya dilakukan dengan pemberdayaan pasar tradisional, antara lain dengan mengupayakan sumbersumber alternatif pendanaan untuk pemberdayaan, meningkatkan kompetensi pedagang dan pengelola, memprioritaskan kesempatan memperoleh tempat usaha bagi pedagang pasar tradisional yang telah ada sebelum dilakukan renovasi atau relokasi, serta mengevaluasi pengelolaan.

Revitalisasi adalah upaya untuk memvitalkan kembali suatu bangunan, kawasan atau bagian kota yang dulunya pernah vital/hidup, akan tetapi kemudian mengalami kemunduran/degradasi. Skala revitalisasi ada tingkatan makro dan mikro. Proses revitalisasi sebuah kawasan mencakup perbaikan aspek fisik, aspek ekonomi dan aspek sosial. Pendekatan revitalisasi harus mampu mengenali dan memanfaatkan potensi lingkungan (sejarah, makna, keunikan lokasi dan citra tempat) (Danisworo dan , 2002).

Revitalisasi sendiri bukan sesuatu yang hanya berorientasi pada penyelesaian keindahan fisik saja, tapi juga harus dilengkapi dengan peningkatan ekonomi masyarakatnya serta pengenalan budaya yang ada. Untuk melaksanakan revitalisasi perlu adanya keterlibatan masyarakat. Keterlibatan yang dimaksud bukan sekedar ikut serta untuk mendukung aspek formalitas yang memerlukan adanya partisipasi masyarakat, selain itu masyarakat yang terlibat tidak hanya masyarakat di lingkungan tersebut saja, tapi masyarakat dalam arti luas (Laretna, 2002).

Proses revitalisasi sebuah kawasan atau bagian kota mencakup perbaikan aspek fisik dan aspek ekonomi dari bangunan maupun ruang kota. Revitalisasi fisik merupakan strategi jangka pendek yang dimaksudkan untuk mendorong terjadinya peningkatan kegiatan ekonomi jangka panjang. Revitalisasi fisik diyakini dapat meningkatkan kondisi fisik (termasuk juga ruang ruang publik) kota, namun tidak untuk jangka panjang. Untuk itu, tetap diperlukan perbaikan dan peningkatan aktivitas ekonomi (economic revitalization) yang merujuk kepada aspek social budaya serta aspek lingkungan (environmental objectives). Hal tersebut mutlak diperlukan karena melalui pemanfaatan yang produktif, diharapkan akan terbentuklah sebuah mekanisme perawatan dan kontrol yang langgeng terhadap keberadaan fasilitas dan infrastruktur kota.

Sebagai sebuah kegiatan yang sangat kompleks, revitalisasi terjadi melalui beberapa tahapan dan membutuhkan kurun waktu tertentu serta meliputi hal-hal sebagai berikut.

\section{Intervensi fisik}

Mengingat citra kawasan sangat erat kaitannya dengan kondisi visual kawasan khususnya dalam menarik kegiatan dan pengunjung, intervensi fisik ini perlu dilakukan. Intervensi fisik mengawali kegiatan fisik revitalisasi dan dilakukan secara bertahap, meliputi perbaikan dan peningkatan kualitas dan kondisi fisik bangunan, tata hijau, sistem penghubung, system tanda/reklame dan ruang terbuka kawasan (urban realm). Isu lingkungan (environmental sustainability) pun menjadi penting, sehingga intervensi fisik pun sudah semestinya memperhatikan konteks lingkungan. Perencanaan fisik tetap harus dilandasi pemikiran jangka panjang.

\section{Rehabilitasi ekonomi}

Perbaikan fisik kawasan yang bersifat jangka pendek, diharapkan bisa mengakomodasi kegiatan ekonomi informal dan formal (local economic development), 
sehingga mampu memberikan nilai tambah bagi kawasan kota (P. Hall/U. Pfeiffer, 2001). Revitalisasi yang diawali dengan proses peremajaan artefak urban harus mendukung proses rehabilitasi kegiatan ekonomi. Dalam konteks revitalisasi perlu dikembangkan fungsi campuran yang bisa mendorong terjadinya aktivitas ekonomi dan sosial (vitalitas baru).

3. Revitalisasi sosial/institusional

Revitalisasi sebuah kawasan akan terukur bila mampu menciptakan lingkungan yang menarik (interesting), jadi bukan sekedar membuat beautiful place. Kegiatan tersebut harus berdampak positif serta dapat meningkatkan dinamika dan kehidupan sosial masyarakat/warga (public realms). Kegiatan perancangan dan pembangunan kota untuk menciptakan lingkungan sosial yang berjati diri (place making) dan hal ini pun selanjutnya perlu didukung oleh suatu pengembangan institusi yang baik.

Paradigma Pengelolaan Pasar TradisionalCaroline Pascarina, dkk (2007) dalam penelitiannya menyimpulkan perlu dilakukan perubahan paradigmapengelolaan pasar, di mana pasar tradisional ditempatkan sebagai investasi jangkapanjang dalam kerangka pengembangan properti kota yang bertujuan untukmeningkatkan, menangkap, dan meredistribusikan kapital bagi kesejahteraanmasyarakat. Kesimpulan ini dilandaskan bahwa konsep revitalisasi pasar tradisional lebih luas dari sekedar perubahan pada fisikbangunannya saja, tetapi juga harus ada konsep bagaimana mendinamiskan pasar. Pengelolaan potensi pasar seyogianya tidak hanya berorientasi pada peningkatan PAD, tetapi berpihak pada kepentingan masyarakat yang lebih luas. Karena itu, dalam menggagas model pengelolaan pasar perlu melibatkan berbagai stakeholders yang terkait.

Revitalisasi Pasar Tradisional Berbasis Kebutuhan Konsumen. Hal yang tidak kalah pentingnya dalam melakukan revitalisasi pasar tradisional adalah memperhatikan kebutuhan pihak pembeli atau konsumen yang diharapkan akan mendapatkan kepuasan dalam memenuhi kebutuhannya. Saat ini, dengan semakin banyaknya toko modern, baik hypermart maupun toko jejaring, berdasarkan hasil banyak penelitian sangat berpengaruh terhadap keberadaan pasar tradisional (Indef, 2007). Hal ini disebabkan adanya perubahan orientasi ekonomi masyarakat. Pasar dalam masyarakat prakapitalistik merupakan pertemuan sosial, ekonomi,dan kultural. Jika keputusan produsen lebih ditentukan oleh harapan untuk mempertahankan posisi pendapatan yang telah dicapai, maka keputusan konsumen lebih dekat pada nilai kolektifyang dapat diraihnya. Sedangkan saat ini pada masyarakat kapitalistik individu secara otonom menentukan keputusan bebas. Dalammasyarakat seperti itu, pasar merupakan kolektivitas keputusan bebas antara produsen dankonsumen (Sastradipoera, 2006: 101). Jika keputusan produsen ditentukan oleh biaya alternatif,harapan laba, dan harapan harga pasar, maka keputusan konsumen ditentukan oleh daya beli,pendapatan minus tabungan, harga dan harapan harga komoditas, serta faktor individual (minat,kebutuhan, dll).

Dengan mengacu pada sepuluh atribut layanan, kajian Indef (2007) menemukan bahwa, konsumen mendudukkan "harga yang murah" padaperingkat pertama kepentingan (paling penting) di antara sepuluh atribut layanan untuk semuakomoditas di pasar tradisional maupun hypermarket. Sementara pasar 
tradisional memilikikeunggulan komparatif dalam atribut-atribut: harga murah dan harga dapat ditawar.

Dari kajian Indef (2007), dalam hal atribut layanan, yang termasuk prioritas kedua salahsatunya adalah peningkatan pelayanan kepada konsumen (keramahan). Atribut ini memilikitingkatan prioritas yang sama baik untuk pasar tradisional maupun hypermarket. Konsumenmenilai bahwa "keakraban" berbelanja di pasar tradisional yang sering disuarakan sebagaikelebihan karakteristiknya dibanding hypermarket tidak menjamin kepuasan konsumen akansegi-segi pelayanan berbelanja. Konsumen semakin mementingkan "keramahan-formalistik"dibanding "keakraban-normatif" sebagai bagian dari ciri-ciri gaya hidup modern.

Selain itu, konsumen mendudukkan atribut"ukuran yang akurat" pada peringkat kedua setelah "harga yang murah". Ini merupakanindikasi kuat akan adanya praktik "kecurangan" pedagang di pasar tradisional, seperti takarandan timbangan yang tidak standar.

Persoalan yang kini dihadapi pasar tradisional bukan hanya pada aspek fisik, institusi dan adanya dampak negatif dari menjamurnya pasar modern. Persoalan yang demikian cenderung mereduksi pasar tradisional sebagai institusi belaka. Padahal sebenarnya pasar juga merupakan ruang dimana terjadi proses sosial yang berlangsung di antara struktur dan relasi sosial antar aktor di pasar yang dipengaruhi oleh nilai-nilai dan sistem tertentu. Aspek sosial inilah sebenarnya yang lebih substantif dari adanya pasar sebagai institusi sosial-ekonomi. Proses sosial merupakan salah satu faktor utama yang turut menjaga keberlangsungan pasar. Proses sosial mencakup adanya aktifitas sosial yang terkandung dalam setiap transaksi ekonomi yang berlangsung dalam pasar Oleh karena itu penting untuk melihat bagaimana proses sosial yang berlangsung di antara struktur dan ikatan sosial antar aktor di pasar. Aktor yang dimaksud adalah pedagang, pembeli, pengelola pasar dan pihak yang terkait dengan kehidupan sosial di pasar.

Salah satu unsur dari proses sosial dalam pasar adalah adanya tindakan ekonomi yang memuat nilai-nilai sosial tertentu. Tindakan ekonomi tidak hanya diartikan sebagai respon timbal-balik antar aktor dalam aktifitas transaksi ekonomis. Lebih dari itu, menurut Granoveter (dalam Damsar, 2007:33), tindakan ekonomi diartikan sebagai suatu proses yang dilakukan individu dalam suatu proses sosial. Dengan kata lain, tindakan ekonomi sangat dipengaruhi oleh struktur, nilai dan relasi sosial serta melekat dalam jaringan hubungan sosial personal yang sedang berlangsung dari para aktor. Tindakan ekonomi yang dilakukan oleh individu dalam hal ini tidak hanya ditujukan demi tercapainya kebutuhan ekonomis yang didominasi oleh perhitungan untung rugi. Tindakan tersebut juga mengandung tujuantujuan atas dasar pertimbangan nilai-nilai tertentu yang melekat dalam jaringan personal. Realitas itulah yang kemudian oleh Granovetter dinamakan keterlekatan (embeddedness).

Keterlekatan menurut Granovetter (dalam Damsar, 2007:139) adalah tindakan ekonomi yang disituasikan secara sosial dan melekat dalam jaringan sosial personal yang berlangsung di antara para aktor. Tindakan ini lebih dari tindakan aktor secara individual karena ia juga mencakup aktivitas ekonomi yang lebih luas seperti penetapan harga dan institusi-institusi ekonomi yang terendap dalam jaringan hubungan sosial. Pedagang di pasar dalam 
melayani

pembelinya

juga

mempertimbangkan adanya kedekatan

hubungan dengannya sehingga

mempengaruhi cara ia memperlakukan

pembeli dan menentukan harga. Pembeli

yang sudah mempunyai hubungan dekat

dengan salah satu pedagang di pasar akan

dapat meraih banyak manfaat dari

kedekatan hubungan tersebut misalnya mendapatkan harga yang lebih murah, informasi tentang kualitas barang yang dibutuhkan dan segala sesuatu di luar transaksi ekonomi tersebut. Dari contoh itu tergambar jelas bahwa pedagang memiliki pertimbangan khusus terhadap pembeli atas dasar adanya hubungan yang telah terjalin dengan pelanggan.

Keterlekatan dalam tindakan ekonomi juga berlaku pada interaksi antar pedagang di pasar. Dalam pandangan ekonomi, antar pedagang diasumsikan terjadi persaingan usaha yang ketat untuk dapat meningkatkan keuntungan masing-masing. Namun dengan adanya keterlekatan antar pedagang di pasar, persaingan usaha dirubah menjadi suatu sikap yang saling mendukung usaha satu sama lain yang disandarkan pada nilai solidaritas sosial. Hubungan yang dibangun oleh para pedagang lebih mengarah pada kerjasama untuk dapat meningkatkan usaha masing-masing dengan cara misalnya membagi informasi tentang dunia usaha, perkembangan harga, atau dalam bentuk kerjasama lainnya. Adanya keterlekatan tentu memberikan manfaat yang besar bagi para pedagang. Namun yang perlu diperhatikan adalah keterlekatan bukanlah suatu tujuan hubungan sosial antar pedagang, melainkan sebuah proses sosial untuk menuju pada tujuan masing-masing. Aspek inilah yang sebenarnya perlu dilihat dan ditingkatkan dalam aktifitas ekonomi di pasar.

Granovetter (1990) dalam bukunya “
The Old and the New Economic Sociology" membagi keterlekatan ke dalam dua bentuk, yakni keterlekatan relasional dan keterlekatan struktural. Keterlekatan relasional adalah tindakan ekonomi dengan pengaruh situasi sosial tertentu yang melekat dalam jaringan personal antar para aktor. Antara penjual dan pelanggan terjalin hubungan interpersonal yang melibatkan aspek sosial, budaya, agama, dan politik. Hubungan yang terjalin antara keduanya lebih merupakan relasi resiprokal, yaitu saling membantu dan membutuhkan satu sama lain. Misalnya ketika pelanggan membeli suatu barang yang ia sendiri sangat minim informasi tentangnya, penjual lantas menjelaskan kepada pelanggan itu terkait harga dan kualitas barangnya. Pertimbangan yang digunakan bukanlah untung rugi, melainkan hubungan interpersonal yang terbangun nilai emosional. Penjual melakukan hal demikian juga karena dilandasi rasa kepercayaan satu sama lainnya sehingga ia tidak ragu membagi informasi dengan pelanggan. Hubungan antara penjual dengan pelanggan bisa jadi tidak hanya berlangsung di pasar, tetapi meluas dalam lingkungan lain misalnya penjual diundang saat pelanggan memiliki hajat atau syukuran.

Sedangkan yang kedua adalah keterlekatan struktural, yaitu keterlekatan yang melibatkan jaringan yang lebih luas seperti institusi atau struktur sosial. Dalam keterlekatan ini, hubungan terjalin tidak hanya antar individu dalam suatu struktur atau institusi tertentu, melainkan juga pada individu dengan struktur lainnya. Struktur sosial sendiri diartikan sebagai pola interaksi atau hubungan yang yang terorganisir dalam suatu ruang sosial (Damsar, 2011:149). Keterlekatan struktural menggambarkan adanya hubungan yang interaktif tidak hanya antar 
personal melainkan individu dengan struktur sosial tertentu. Nilai-nilai yang dibangun dari keterlekatan ini dipengaruhi oleh adanya kedekatan hubungan dan kesamaan tujuan masing-masing. Maksudnya adalah tindakan antara individu dengan struktur mencerminkan sebuah relasi timbal balik atas dasar tujuan tertentu. Jadi struktur sosial dalam hal ini tidak mendominasi dan memaksakan kepentingannya pada individu agar sesuai harapannya.

Dalam suatu pasar, interaksi terjadi dengan melibatkan banyak aktor baik dari penjual, pembeli, pemasok barang dan pengelola pasar. Meskipun masing-masing aktor terkadang tidak terlibat dalam interaksi tertentu, namun mereka terjalin dalam hubungan yang tidak langsung. Misalnya interaksi antara pengunjung dan pengelola pasar tidak terjadi secara langsung namun pengelola pasar memperlakukan pengunjung tidak sebatas konsumen yang perlu dilayani atas pertimbangan untung rugi. Pengelola pasar melayani pengunjung karena memiliki tanggung jawab sebagai pemerintah yang menyediakan fasilitas publik yang kondusif dan memadai. Pengunjung pun sebenarnya juga dapat menjalin hubungan dengan pengelola pasar melalui interaksi tidak langsung seperti surat atau melalui teknologi informasi untuk memberikan kritik dan saran demi terciptanya pasar yang baik. Pengunjung memposisikan pengelola pasar sebagai mitra untuk kepentingan bersama terkait kondisi pasar yang ideal.

Adanya keterlekatan struktural dalam tindakan ekonomi di pasar tradisional dapat mendorong terselenggaranya relasi dan jaringan sosial yang tidak hanya sebatas transaksi jual beli. Tindakan ekonomi di pasar dalam hal ini hanya sebagai representasi dari proses sosial yang di dalamnya terdapat interaksi yang intim antara pedagang, pembeli dan pihak pengelola pasar. Apabila hal tersebut sudah terbentuk, maka pengunjung akan merasa nyaman berbelanja di pasar karena mereka menganggap pasar adalah sebagai ruang publik yang tidak sebatas untuk transaksi. Ketika pasar sudah dianggap sebagai ruang publik, maka pengunjung dapat melakukan aktifitas belanja dengan leluasa tanpa dibayangi rasa takut dicurangi pedagang atau menjadi korban permainan harga. Implikasi yang lebih kompleks adalah proses sosialisasi kebijakan dan programprogram dari pasar akan dapat tersampaikan dengan baik. Sosialiasi yang terbangun akan terlaksana secara interaktif, yakni adanya respon timbal balik pedagang, pembeli dan pengelola pasar. Berikut ini gambaran hubungan resiprokal antara pedagang, pembeli dan pengelola pasar.

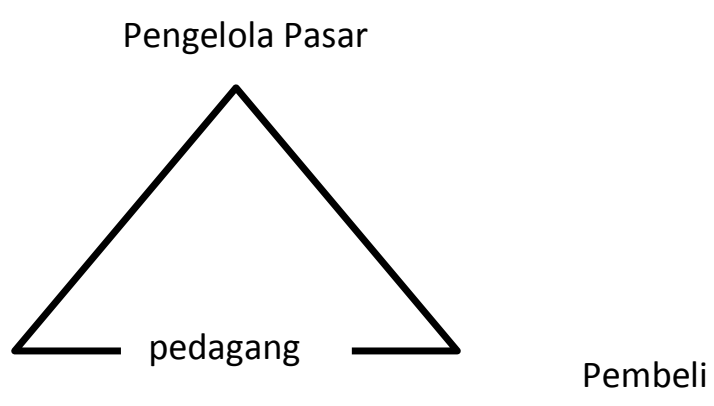

\section{Diagram Hubungan Resiprokal antara Pedagang, Pembeli dan Pengelola Pasar}

Untuk dapat melihat bagaimana kualitas keterlekatan baik personal maupun struktural, perlu menggunakan dari intensitas, bentuk dan cara interaksi dilakukan. Dan yang paling penting adalah apa yang menjadi poin dari interaksi tersebut. Kedua, adanya rasa kepercayaan yang terendap dalam setiap interaksi, misalnya bagaimana pedagang menaruh kepercayaan pada pengelola pasar untuk 
mengelola pasar agar menjadi kondusif. Ketiga, adanya nilai-nilai yang mendasari terbentuknya keterlekatan dalam setiap hubungan antar aktor. Misalnya nilai agama, solidaritas, budaya dan lain-lain. Ketiga poin tersebut dapat digunakan sebagai acuan dalam melihat kualitas keterlekatan baik relasional maupun struktural dalam pasar.

\section{METODE PENELITIAN}

Penelitian dilakukan dengan lima pendekatan: Pendekatan dari aspek fisik, ekonomi, manajemen, lingkungan dan sosial budaya. Khususnya aspek fisik dan aspek lingkungan akan dijadikan satu bahasan menjadi aspek lingkungan fisik.

Metode penelitian dalam menyusun Studi Revitalisasi Pasar Pleret ini menggunakan metode analisis deskriptif. Penelitian deskriptif bermaksud untuk memberikan uraian mengenai suatu gejala sosial yang diteliti. Peneliti mendeskripsikan suatu gejala berdasarkan pada indikator-indikator yang dijadikan dasar dari ada tidaknya suatu gejala yang diteliti.

Penelitian ini disusun melalui serangkaian proses dari pengumpulan data dan informasi, penulisan hingga penyempurnaan penelitian yang dilakukan melalui diskusi terbatas dengan sejumlah stakeholder Pasar Pleret baik pengelola maupun berbagai komunitas/paguyuban yang ada di pasar. Setidaknya ada tiga metode utama yang digunakan yakni:

1. Desk Study dilakukan dengan mengumpulkan data dan informasi, baik dari literatur, Kantor Pengelolaan Pasar dan instansi terkait. Selain itu, juga dilakukan observasi awal oleh tenaga ahli untuk melihat secara langsung kondisi pasar yang menjadi obyek penelitian sehingga memiliki gambaran awal ruang lingkup penelitiaan yang akan dilakukan.

2. Focus Group Discussion (FGD)/Indepth Interview. FGD ini melibatkan sejumlah stakeholder pengelola Pasar Pleret. Forum FGD dilakukan untuk memperoleh keterangan dari pihak pelaku atau pelaksana pelayanan pasar.

3. Survei dilakukan kepada pedagang dan pembeli. Pengambilan sampel dilakukan dengan teknik Proportionate Stratified Random Sampling, Teknik ini dilakukan karena populasi mempunyai anggota/unsur yang tidak homogen dan bersetrata secara proporsional, sehingga responden pedagang diambil 30 orang sementara pembeli diambil 40 orang.

\section{a. Instrumen Survey}

Salah satu metode yang digunakan untuk mengidentifikasi permasalahan di pasar adalah denganmendengarkan atau mengumpulkan persepsi dari responden yang berkaitan mengenai aspek lingkungan fisik, ekonomi, manajemen dan social budaya. Instrumen yang dipergunakan untuk mengumpulkan persepsi responden adalah kuisioner. Jenis kuisioner yang digunakan ialah jenis kuisioner kombinasi antara angket terbuka dan angket tertutup, di mana dalam angket tersebut, memberi kesempatan kepada responden untuk menjawab dengan kalimat sendiri. Maupun yang sudah disediakan jawabannya sehingga responden tinggal memilih ( Suharsimi Arikunto (2006: 224).

Untuk dapat mengidentifikasi permasalahan mengenai aspek fisik, aspek ekonomi, dan aspek sosial, maka perlu menggunakan indikator-indikator sebagai berikut: 
1) Aspek dan Indikator Sampel Pedagang

\begin{tabular}{|l|l|}
\hline \multicolumn{1}{|c|}{ Aspek } & \multicolumn{1}{c|}{ Indikator } \\
\hline Lingkungan Fisik & Kondisi bangunan \\
\hline & Penataan lingkungan pasar \\
\hline & Fasilitas pasar \\
\hline Ekonomi & Latar belakang berdagang \\
\hline & Modal dan pendapatan berdagang \\
\hline Manajemen & Tumbuh kembang dan Penghambat berdagang \\
\hline & Peran Aktif Koperasi Pasar \\
\hline & Peran Aktif Paguyuban Pasar \\
\hline Sosial & Pengelolaan waktu operasional buka \\
\hline & Interaksi dan Solidaritas Pedagang \\
\hline & Peran Komunitas Pedagang \\
\hline & Interaksi dengan Pengelola Pasar \\
\hline
\end{tabular}

2) Aspek dan Indikator Sampel Pembeli

\begin{tabular}{|l|l|}
\hline \multicolumn{1}{|c|}{ Aspek } & \multicolumn{1}{c|}{ Indikator } \\
\hline Lingkungan Fisik & Kondisi bangunan \\
\hline & Penataan lingkungan pasar \\
\hline & Fasilitas pasar \\
\hline Ekonomi & Atribut layanan pasar tradisional \\
\hline & Preferensi pada pasar modern \\
\hline & Kesan pasar tradisional lebih murah \\
\hline Manajemen & Pengelolaan Organisasi pasar yang baik \\
\hline & Perlunya Koperasi dan Paguyuban Pedagang \\
\hline & Pengelolaan Wakti Operasional buka \\
\hline Sosial & Interaksi dengan pedagang \\
\hline & Interaksi dengan Pengelola Pasar \\
\hline & Interaksi antar pembeli \\
\hline
\end{tabular}

\section{b. Populasi dan Sampel Survey}

Populasi survey penelitian ini ialah Pasar Pleret, populasi sendiri tidak hanya sekedar jumlah yang ada pada obyek/subyek yang dipelajari, tetapi meliputi seluruhkarakteristik/sifat yang dimiliki oleh subyek atau obyek tersebut (Sugiyono,2010:117). Pengambilan sampel dimana sampel bagian dari jumlah dan karakteristik yang dimiliki oleh populasi, dengan cara teknik proportionate Stratified Random Sampling. Teknik tersebut menjamin represantasi kelompok sampel ; karakteristik setiap sampel dapat teridentifikasi (Muhammad,2011:178), sehingga sampel yang diambil ialah sampel pedagang dan pembeli.
Untuk responden Pedagang diambil 30 orang, sedangkan dengan responden Pembeli diambil sebanyak 30 orang. Ini sesuai oleh Roscoe (1975) yang menyarankan apabila sampel dibagi dalam katagori maka jumlah sampel setiap kategori minimal 30.

\section{c. Diagram Tahapan Kajian}

\section{HASIL PENELITIAN}

\section{A. Aspek Lingkungan Fisik}

\section{Akses Eksternal Pasar dan Internal Pasar.}

Pasar Pleret merupakan salah satu pasar tradisional yang cukup ramai di Kabupaten Bantul, terletak di lokasi strategis yakni di Dusun Kauman, Desa Pleret, Kecamatan Pleret. Pasar ini masuk 
kategori kelas II dengan luas tanah \pm $6.150 \mathrm{~m}^{2}$ dan merupakan tanah Pemerintah.

Pasar ini dilengkapi dengan fasilitas tempat parkir, tempat ibadah, kantor pengelola, $\mathrm{KM} / \mathrm{WC}$, sarana pengelolaan kebersihan, sarana pengamanan, sarana air bersih, instalasi listrik, penerangan umum

Berdasarkan hasil obeservasi, bahwa pada saat pasaran Pon atau Kliwon maka pasar pleret ini buka. Terdaftar sebanyak 514 pedagang berjualan pada saat pasar buka dan kondisi jalan yang melingkari pasar Pleret terjadi padat lalu lintas, karena memang banyak kendaraan baik roda dua maupun empat yang diparkir di bahu jalan sehingga jalan utamanya menjadi sempit. Ini menandakan bahwa pengaturan Tempat parkir pengunjung maupun parkir kendaraan bongkar muat barang sudah sangat mendesak dipikirkan. Karena jumlah pedagangnya cukup banyak maka banyak juga pedagang yang hanya menempati tempat di selasar Los pasar sehingga sirkulasi dan aliran jalan di sela Los menjadi sempit, hal ini juga membuktikan bahwa Zonasi, pengaturan dan ketertiban harus segera dilakukan.

Kios kios di sisi selatan sudah tidak berfungsi layaknya sebuah Kios untuk berdagang sehingga harus segera dibongkar dan diperbaiki agar pasar bisa menjadi lebih tertata dan nyaman digunakan untuk bertarnsaksi.

\section{Penataan Lingkungan Fisik Pasar}

Berdasarkan hasil survey ada beberapa isu penting terkait dengan penataan lingkungan fisik Pasar Pleret, diantaranya perombakan wajah pasar Pleret, penataan pedagang di Selasar/koridor Los pasar, dan penataan akses masuk Pasar Pleret dengan Mengoptimalkan Tempat Parkir di sisi selatan dalam pasar.

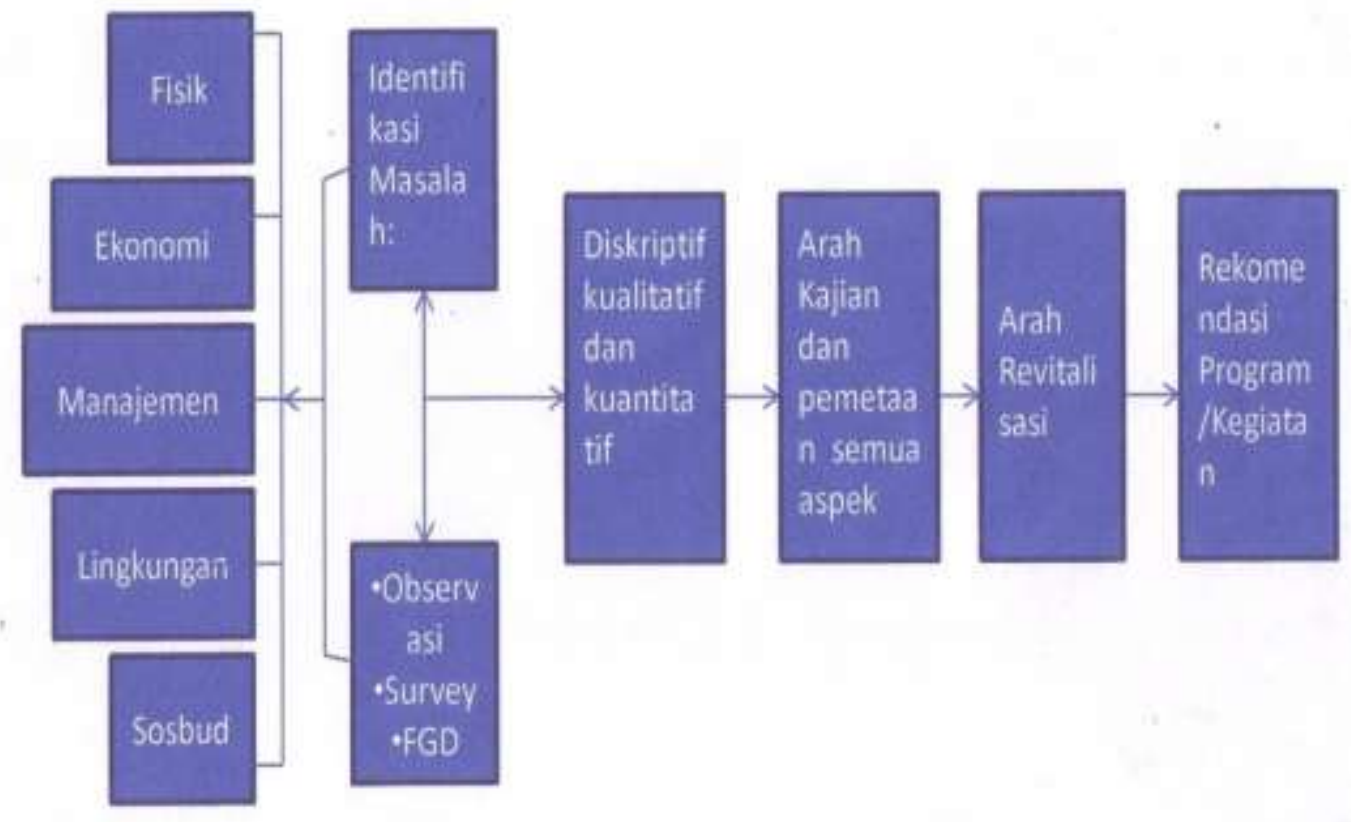

Semua pedagang (100\%) tidak ada saat ini. Persamaan pandangan antara mempersoalkan jalur sirkulasi, begitu juga pedagang dan pembeli juga terjadi pada dari pihak pengunjung (90\%) merasa penataan zonasi. Sebanyak $80 \%$ nyaman dengan kondisi jalur sirkulasi yang pengunjung menyatakan setuju, bahkan 
diantaranya30\% ada yang sangat setuju, terhadap penataan zonasi. Sama halnya dengan semua pedagang (100\%) setuju. Persamaan pandangan ini menunjukkan bahwa adanya anggukan universal yang baik terhadap penataan lingkungan fisik pasar diantara keduanya. Namun demikian, adanya tantangan eksternal (pasar modern) bagi keberlanjutaan pedagang Pasar Pleret, maka dalam perencanaan revitalisasi pemenuhan terhadap kebutuhan pembeli perlu mendapatkan perhatian lebih tanpa harus mengorbankan kepentingan pedagang di sisi yang lain.

Masalah parkir ini berhubungan dengan aksesibiltas eksternal bagi pedagang maupun pengunjung, disamping aspek keamanan dan kenyamanannya. Pedagang dan pengunjung memang sudah menilai negatif terhadap pengelolaan parkir di Pasar Pleret saat ini karena mengganggu aksesibiltas eksternalnya. Namun, jika nanti disisi selatan pasar dilakukan perluasan vertikal, maka mestinya juga dibarengi dengan dilakukannya penataan parkir sehingga masalah aksesbilitas eksternal tetap masih bisa diterima terutama bagi pedagang di kios lantai 2 nantinya.

Pada sisi sebelah barat di pasar hewan juga perlu perhatian serius, sehingga jika akan diadakan rehabilitasi maka harus memikirkan sekat dan batas yang jelas dan aman dengan pasar utamanya. Pada sisi Utara pasar merupakan pintu belakang namun harus dipikirkan bagaimana pagar itu ditinggikan dengan ornament yang khas budaya Pasar pleret. Jadi tidak hanya untuk keamanan pasar tetapi juga untuk kepentingan estetika.

\section{a. Solusi Revitalisasi Pasar Pleret.}

Aksesbilitas internal dan eksternal bagi pasar tradisional merupakan variabel yang penting dalam merencanakan revitalisasi. Memperhatikan pembahasan pada dua bagian sebelumnya, agar bisa mengakomodir semua kepentingan pedagang dan pembeli, program revitalisasi pasar Pleret adalah pada aspek wajah pasar dan akses masuk ke lokasi pasar. Ada beberapa catatan yang harus diperhatikan terkait dengan perencanaan ini, diantaranya:

1) Rencana perubahan wajah pasar harus bisa memunculkan kesan Khas Budaya atau area depan pasar berbentuk unik sebagai salah satu cagar Budaya di Pleret.

2) Perlu dibangun area untuk publik khususnya untuk warga masyarakat sekitar guna kegiatan sosial kemasyarakatan, oleh raga dan seni budaya.

3) Pembuatan area kuliner khas Kabupaten Bantul dan area free hot spot.

4) Pembuatan pusat oleh-oleh untuk menyemarakkan pasar Pleret dan mendukung Kawasan wisata di pleret.

Rancangan disain jadilengkap dengan pengelolaan Drainase yang baik, daripengembangan Pasar Pleretsudah berada di kantor PU yang tahun 2016 ini akan segera direalisasikan, sehingga dalam Laporan Akhir ini tidak disertakan desain pengembangan fisik.

\section{b. Fasiltas Pasar Pleret}

Berdasarkan hasil survey menunjukkan bahwa fasilitas yang ada di Pasar Pleret secara keseluruhan kondisinya baru 'cukup' memberikan kenyamanan bagi pedagang maupun pengunjung. Karena nilai kepuasan pedagang terhadap fasilitas hanya sebesar 2,46 saja. Jenis fasilitas yang memberikan sumbangan besar terhadap kondisi hanya'cukup' ini diantaranya fasilitas Pelayanan persampahan, jringan air kotor, drainase, pengelolaan parker dan tempat bongkar muat. 


\section{B. Aspek Ekonomi}

\section{Perkembangan Usaha Pedagang}

Pasar Pleret yang berlokasi di Dusun Kauman, desa Pleret Kecamatan Pleret dengan segmen pasar yang berasal dari masyarakat kelas menengah ke bawah semestinya akan memberikan potensi berkembang kepada para pedagang di dalamnya. Namun hanya 23\%pedagang yang menyatakan usaha dagangnya mengalami peningkatan. Mayoritas pedagang 46,7\% menyatakan Stagnan/tetap dan $20 \%$ menyatakan kondisi nya naikturun, bahkan terdapat $10 \%$ pedagang mengakui mengalami penurunan. Pedagang yang mengalami penurunan ini adalah mereka yang berjualan sembako, buahbuahan dan sayuran. Sedangkan yang menyatakan stagnan terjadi pada hampir semua jenis dagangan, terutama sembako.

Salah satu penjelas yang relevan terhadap kondisi perkembangan usaha pedagang Pasar Pleret ini adalah adanya budaya belanja para pembeli yang sudah banyak beralih ke pasar modern walaupun secara letak, di sekitar area pasar Pleret jauh dari pasar modern. Sebagai penguatnya adalah bahwa pengunjung Pasar Pleret menyatakan selalu belanja di pasar modern saat pasar pleret tutup yaitu sebesar $100 \%$ Sementara bila dicermati lagi komoditas yang sering dibeli di pasar modern oleh pengunjung pasar tradisional adalah sembako, buah-buahan, pakaian dan perabot rumah tangga. Jadi terlihat bahwa yang paling terpengaruh dengan keberadaan pasar modern adalah pedagang pakaian dan perabotan rumah tangga dan sebagian dari mereka lah yang menyatakan usahanya mengalami penurunan atau tetap stagnan.

\section{Faktor-faktor Penguat dan Penghambat}

Sesungguhnya ada beberapa faktor penguat yang memungkinkan untuk mendorong peningkatan pertumbuhan ekonomi pelaku Pasar Pleret. Adanya keterlekatan struktural dalam relasi antar pedagang dan juga dengan pihak lain serta sikap rasionalitas pedagang dalam menyikapi dinamika yang ada merupakan modal penting untuk menumbuhkan motivasi dan kemauan untuk mau berkembang dan memajukan usaha dagangnya.

Faktor penguat lainnya dapat dilihat dari perspektif pengunjung yaitu berdasarkan faktor-faktor yang menjadi alasan pengunjung berbelanja ke Pasar Pleret. Faktor-faktor yang menjadi alasan tersebut menggambarkan tingkat kepuasan pengunjung terhadap kondisi pedagang dan Pasar Pleret secara keseluruhan. Tingkat kepuasan ini sesungguhnya menjadi faktor penguat dalam pengembangan Pasar Pleret. Sebagaimana ditunjukkan pada Tabel 4.8. di Bab sebelumnya, ada beberapa alasan yang nilai bobotnya tinggi diantaranya adalah pedagang yang ramah, hubungan pelangganan, adanya proses tawar menawar dalam transaksi, sikap pedagang yang menghargai pembeli, harga yang murah, pembeli mudah mendapatkan yang mereka butuhkan, dan kondisi pasar yang aman. Dengan mempertahankan atau bahkan meningkatkan faktor-faktor tersebut akan semakin meningkatkan loyalitas pembeli.

Sementara yang menjadi faktor penghambat dalam peningkatan pertumbuhan Pasar Pleret, sebagai hasil survey, adalah keberadaan pasar modern yang sudah menjamur sehingga menyebabkan beralihnya budaya belanja dan persaingan tidak sehat antar pedagang. Maraknya pasar modern merupakan faktor 
eksternal pedagang yang hanya bisa diatasi dengan berusaha mencari terobosan solusi agar tingkat kepengaruhannya dikurangi atau bahkan dihilangkan. Sementara untuk faktor persaingan yang tidak sehat antar pedagang tidak terungkap secara detail. Hal ini diperkuat dengan hasil analisis sosial yang menunjukkan rendahnya ikatan keterlakatan antar pedagang.

\section{Aspek Manajemen}

Pendekatan manajemen berbasis komunitas (base community management) menempatkan unsur pemerintah (melalui Dinas Pasar dan Instansi terkait), warga pasar dan stakeholder lain dalam sebuah transparansi komunikasi dan saling mempercayai sehingga suasana pasar nyaman dan aman bagi kelangsungan usaha para pedagang dan komponen pasar lainnya.

Dalam era otonomi daerah, pemerintah melaksanakan perannya sebagai fasilitator, inisiator sekaligus sebagai funding pembangunan pasar, yaitu pembangunan yang bertujuan menciptakan kesejahteraan serta keadilan bagi masyarakat, dan akan lebih tepat sasaran jika masyarakat pasar ikut serta menentukan agenda pembangunan. Inilah salah satu paradigma pemerintah sebagai public service yang menganut prinsip demokrasi dalam mengoptimalkan peran serta masyarakat, pemerataan dan keadilan, serta keanekaragaman potensi daerah.

Manajemen komunitas sebagai pendekatan terhadap pemecahan persoalan yang ada dibangun berdasarkan asumsi bahwa komunitas inilah yang paling merasakan persoalan, mengerti permasalahan, dan mengerti (sebagian) pemecahannya. Berdasarkan asumsi ini, maka pembangunan manajemen komunitas secara internal dengan melibatkan pemerintah, asosiasi lokal, pengusaha, perguruan tinggi serta stakeholder lainnya perlu duduk dan dibangun bersama untuk mencegah dan mengatasi berbagai factor krisis yang ada dan mungkin terjadi di pasar. Salah satu Komunitas di pasar yang pada saat ini sudah ada yaitu Paguyuban Pedagang. Semua Pedagang setuju kepentingan bersama dipikirkan melalui Paguyuban dan Koperasi (100\%), Mereka juga setuju wajib menjadi anggota koperasi dan Paguyuban pedagang dan peraturan dan tata tertib yang dikeluarkan akan diikuti dan dipatuhi bersama.

Keberadaan Koperasi dan Paguyuban akan memberikan peningkatan pengelolaan pasar secara baik dan mandiri, para pedagang akan terikat ke dalam suatu wadah yang pada saatnya akan menjadi tumpuan hidupnya. Kalau falsafah itu sudah didapat maka mengatur berapapun pedagang tentu tidak ada kesulitan dan kendala yang berarti.

Untuk meningkatkan produktifitas pasar Pleret, maka diusulkan kalau pasar tidak lagi hanya buka pada pasaran Pond an Kliwon, akan tetapi Pasar Pleret akan buka setiap hari yaitu semua pasaran, dari hasil survey menunjukkan bahwa semua pedagang setuju sebanyak $100 \%$ bahwa pasar Pleret Dibuka setiap hari.

\section{Aspek Sosial}

\section{Struktur Sosial di Pasar Pleret}

Struktur sosial merupakan pola hubungan yang terjalin dalam unsur-unsur sosial tertentu. Di dalam pasar tradisional, struktur sosial yang paling mendasar adalah penjual dan pembeli. Namun dalam perkembangannya, struktur sosial di pasar tradisional bertambah dengan menyertakan pihak pengelola dan paguyuban. Perkembangan struktur ini disebabkan oleh diterapkannya manajemen pengelolaan 
organisasi modern dalam aktifitas pasar tradisional. Dengan perkembangan tersebut, relasi sosial di pasar tradisional lebih banyak melibatkan aktor-aktor yang dapat mempengaruhi pola interaksinya seharihari. Hubungan yang terjadi tidak lagi hanya bersifat transaksional antara penjual dan pembeli, namun juga hubungan organisasional dengan paguyuban dan pengelola pasar dimana masing-masing memiliki peran tersendiri. Oleh karena itu, Pola relasi sosial dalam sistem di pasar tradisional menjadi semakin kompleks.

Pasar Pleret, sebagai pasar tradisional, secara struktural memiliki empat unsur struktur sosial, yakni pedagang, pembeli, paguyuban dan pengelola pasar. Pedagang adalah yang pihak utama yang paling berkepentingan dalam aktifitas di pasar. Dari 30 responden pedagang, semua pedagang berasal dari kabupaten Bantul yaitu sebanyak $100 \%$.

Dari keseluruhan responden, semua pedagang adalah perempuan yakni sebanyak 30 orang atau $100 \%$. Kenyataan tersebut menunjukkan bahwa kegiatan jual beli di Pasar Pleret didominasi oleh pedagang perempuan. Usia mayoritas pedagang adalah diatas 40 sebanyak $87 \%$. Hal ini mengindikasikan pedagang di Pasar Pleret adalah individu yang sudah melewati usia produktif. Meskipun demikian kondisi tersebut tidak terlalu berpengaruh karena aktifitas transaksi mereka tidak terlalu membutuhkan banyak tenaga dan menuntut keterampilan tertentu. Tingkat pendidikan pedagang adalah SMA sebanyak $67 \%$ dan sisanya SMP 33\%, hal tersebut tidak terlalu berdampak signifikan terhadap aktifitas di pasar. Alasannya adalah sebagian besar pedagang menjual komoditas yang tidak membutuhkan dua prasyarat di atas, yakni pedagang sembako sebanyak $13,3 \%$ dan pedagang sayuran $16,7 \%$.
Unsur kedua dari struktur sosial di Pasar Pleret adalah pengunjung/pembeli. Jika melihat hasil statistik, mayoritas pengunjung Pasar Pleret memiliki tujuan untuk belanja dan dijual lagi yaitu sebesar $75 \%$ dan yang berbelanja untuk kepentingan rumah tangga sebesar $22,5 \%$. Sisanya 3,3\% untuk bahan warungan. Ini menunjukkan bahwa mayoritas pengunjung yang datang ke pasar Pleret adalah pedagang juga. Kebanyakan dari pengunjung memiliki tingkat pendidikan mayoritas adalah SMA sebanyak $75 \%$ dan pekerjaan wiraswasta sebanyak $90 \%$. Sebagian besar dari mereka adalah pengunjung berumur 30-40 tahun sebanyak $62,5 \%$. Tujuan dari pengunjung pasar membeli komoditas di Pasar Pleret berbeda, yakni sebanyak $75 \%$ untuk kulakan dan sebanyak $22,5 \%$ untuk memenuhi kebutuhan rumah tangga. Data tersebut menggambarkan bahwa Pasar Pleret memiliki segmentasi pembeli dari golongan ekonomi menengah ke bawah.

Sedangkan unsur struktur sosial yang ketiga di Pasar Pleret adalah paguyuban pedagang. Pasar Pleret memiliki paguyuban yang dibentuk untuk merekatkan hubungan antar pedagang dan mewadahi aspirasi serta memediasi arus informasi. Bentuk kegiatannya adalah musyawarah. Namun tidak semua pedagang selalu aktif mengikuti pertemuan di paguyuban. Hanya $63,3 \%$ pedagang yang aktif di kegiatan paguyuban. Paguyuban membuka ruang kolektifitas dan musyawarah antar pedagang untuk merekatkan ikatan sosial dan menyampaikan aspirasi mereka.

Unsur struktur sosial di Pasar Pleret yang terakhir adalah pengelola pasar. Pihak pengelola pasar bertugas mengatur seluruh aktifitas dan fasilitas di Pasar Pasar.

Keberadaan pengelola pasar ini sebenarnya menjadi kepanjangan tangan 
dari pemerintah di bawah dinas pengelolaan pasar Kabupaten Bantul. Adanya pengelola pasar sangat membantu kelancaran aktifitas di pasar, terutama sebagai mediator arus informasi dan kebijakan pemerintah. Pengelola pasar juga membantu menyelesaikan permasalahan di tingkat internal pasar sehingga tidak berlarut-larut. Fungsi pengelola pasar berikutnya adalah untuk mengorganisir dan memudahkan koordinasi antara pedagang dan pemerintah sehingga kebijakan pemerintah dapat tersampaikan dengan baik.

\section{Interaksi Sosial di Pasar Pleret}

Setiap individu yang beraktifitas di pasar adalah homo sosiologicus, yakni individu yang menginterpretasikan tindakan ekonomi ke dalam sistem hubungan sosial yang sedang berlangsung. Dengan demikian, individu di pasar bukan hanya sebagai aktor ekonomi, melainkan juga aktor sosial yang menjalin hubungan sosial satu sama lain. Dalam hal ini, pengelola pasar, paguyuban, pedagang dan pembeli juga termasuk aktor ekonomi yang tidak terlepas dari proses sosial di pasar, terutama interaksi sosial antar aktor. Interaksi sosial menjadi sangat vital diperlukan mengingat masing-masing aktor mempunyai peran sinergis dalam lingkup struktur tertentu. Interaksi sosial tersebut berlangsung dalam struktur besar institusi pasar yang membawahi unsur-unsur yang saling bersinergis untuk menjalankan suatu tujuan tertentu. Oleh karena itu interaksi sosial perlu dilihat dan dikondisikan agar dapat memperlancar aktifitas di Pasar Pleret

Interaksi sosial antar aktor di tiap struktur di Pasar Pleret termasuk kuat. Kuatnya interaksi sosial tersebut tampak dari jalinan komunikasi di antara mereka. Dalam lingkup antar pedagang, pola interaksi berlangsung baik dan hangat. Hal tersebut ditunjukkan oleh intensitas interaksi mereka di mana sebanyak $76 \%$ pedagang mengaku setiap hari berinteraksi dengan pedagang lainnya. Sedangkan $16,7 \%$ pedagang lainnya menyatakan jarang berinteraksi satu sama lain. Konten dari interaksi mereka tidak sebatas komunikasi formal yang berkaitan dengan kegiatan jual beli, namun lebih pada perbincangan biasa seperti bercanda, menanyakan kabar keluarga dan lain-lain. Sebanyak 19 responden pedagang mengungkapkan perbincangan mereka kebanyakan seputar obrolan biasatentang keluarga. Data tersebut menggambarkan eratnya ikatan emosional dalam interaksi antar pedagang di sela kesibukan transaksi ekonomi.

Meskipun sebenarnya terdapat persaingan usaha yang menjadi penghambat di antara pedagang, namun secara umum interaksi sosial relatif kuat. Sebanyak 23\% pedagang menganggap persaingan usaha menjadi hambatan dalam mengembangkan usaha. Bentuk persaingan negatif tersebut adalah permainan harga, informasi kualitas barang yang asimetris. Namun hal itu tidak menjadi persoalan serius karena sebanyak $60 \%$ pedagang menganggap hambatan terbesar mereka adalah keberadaan pasar modern. Kuatnya interaksi sosial antar pedagang juga terlihat dari sikap mereka ketika mengetahui pedagang lainnya lebih berhasil dari pada dirinya. Sebanyak 53\% pedagang memilih memperbaiki diri, sedangkan $10 \%$ pedagang lebih ingin mempelajari cara berdagang agar bisa berkembang.

Interaksi sosial antara pedagang dengan pihak pengelola pasar pun juga relatif baik. Kedua pihak terjalin dalam ikatan sosial yang kondusif. Pengelola pasar seringkali bersosialisasi dengan para pedagang secara langsung dengan berbagai kepentingan seperti, pengontrolan, interaksi biasa, ataupun menyampaikan informasi. 
Sebanyak $100 \%$ pedagang mengakui bahwa pengelola bersosialisasi secara langsung. Sebanyak $92,7 \%$ pedagang menyatakan pentingnya menjalin interaksi dengan pengelola pasar. $20 \%$ dari mereka juga tidak segan menyampaikan saran dan kritik pada pengelola secara langsung. Hal tersebut menggambarkan bahwa antara pedagang dan pengelola pasar terjalin ikatan sosial yang kuat tanpa terpengaruhi perbedaan tingkat struktur di antara mereka.

Interaksi sosial antara pedagang dan pembeli dapat dikatakan relatif baik. Kondisi tersebut dikarenakan beberapa faktor, terutama sikap baik yang ditunjukkan pedagang. Sikap baik tersebut salah satunya adalah keramahan pedagang pada pengunjung pasar. Sebanyak bobot nilai 104 pembeli mengaku alasan mereka membeli barang kebutuhan di Pasar Pleret adalah karena sikap pedagang yang ramah. Pedagang di Pasar Pleret memang menampakkan keramahan kepada pengunjung dengan nilai lebih dari standarnya, dari pedagang selalu menanyakan barang kebutuhan pembeli saat melintas di depan lapaknya. Sebagian lagi lebih menawarkan barang dagangannya kepada pengunjung yang lewat.

Interaksi sosial yang kuat di samping menjadi strategi pemasaran juga menumbuhkan kehangatan komunikasi antara pedagang dan pembeli. Kehangatan komunikasi ini menjadi faktor penting motif pengunjung membeli di Pasar Pleret. Proses tawar-menawar harga pun berlangsung kondusif melalui kehangatan komunikasi yang terbangun. Meskipun $42,5 \%$ dari pengunjung menyatakan hanya sebatas kenal dengan pedagang di Pasar Pleret, namun jika interaksi keduanya dikembangkan dengan baik akan menciptkan relasi sosial yang lebih kuat. Hal ini juga diakui sebagian pedagang bahwa hubungan mereka dengan pembeli tidak sebatas di dalam pasar saja, melainkan di luar pasar. Misalnya adanya undangan bagi pedagang untuk menghadiri hajatan di rumah pembeli.

Interaksi sosial pembeli tidak hanya berlangsung dengan pedagang saja, melainkan dengan pengelola pasar. Meskipun pada dasarnya tidak ada interaksi langsung dengan pengelola pasar, namun mereka dapat berinteraksi melalui media tertentu. Namun, saat ditanya bagaimana cara pembeli jika ingin menyampaikan saran dan kritik pada pengelola, Sebanyak $12,5 \%$ pembeli menyatakan menemui pengelola secara langsung. Kualitas hubungan yang baik ini jika mampu dikembangkan dapat membangun lingkungan pasar yang kondusif bagi aktifitas transaksi sehingga pengunjung merasa nyaman bertransaksi di Pasar Niten. Karena sejatinya peran dan fungsi pasar adalah sebagai locus transaksi untuk mengurangi informasi yang asimetris, menekan biaya transaksi dan meningkatkan kepercayaan (Leksono, 2009). Dari kondisi demikian, intensitas pengunjung di Pasar Pleret dapat meningkat.

\section{Norma-norma Sosial-Budaya di Pasar Pleret}

Di dalam Pasar Pleret berkembang nilai dan norma sosial budaya yang mewarnai proses sosial sehari-hari. Beberapa nilai dan norma tersebut antara lain Solidaritas, gotong royong, toleransi dan kepercayaan. Nilai solidaritas adalah nilai yang merekatkan antar pedagang melalui ikatan sosial. Ikatan sosial tersebut didasari oleh rasa sepenanggungan, kekeluargaan dan dorongan psikologis. Ikatan solidaritas pedagang di Pasar Pleret terlihat dari sikap mereka saat menghadapi masa-masa sulit dalam mengembangkan usaha, terutama ketika melihat pedagang 
lain mengalami kesulitan. Kondisi pasar yang semakin menurun tidak turut menurunkan kualitas interaksi antar pedagang. Meskipun persaingan untuk merebut konsumen semakin ketat namun mereka tetap menjalin relasi sosial yang relatif baik. Kedekatan hubungan antar pedagang karena merasa sepenanggungan dan seperjuangan di dalam pasar menjadi pengikat interaksi mereka. Bentuk kerjasama lainnya adalah saling menitipkan barang dagangan sebanyak 35,5\% pedagang, berbagi informasi harga dan usaha sebanyak $35,5 \%$ pedagang.

\section{Relasi Sosial antara Pedagang, Pembeli dan Pengelola di Pasar Pleret}

Relasi sosial yang terbangun dalam struktur Pasar Pleret terjalin di antara empat unsur yang menduduki tingkat dan peranan tertentu. Unsur tersebut adalah pengelola pasar, paguyuban, pedagang dan pembeli. Masing-masing unsur tertambat dalam pola jaringan yang melekat dalam proses sosial sehari-hari. Sebagaimana dijelaskan Granovetter (1985), keterlekatan adalah tindakan ekonomi yang disituasikan secara sosial dan melekat dalam jaringan sosial personal yang sedang berlangsung dari para aktor. Keterlekatan menjadi kekuatan solidaritas dalam mekanisme pasar tradisional.

Granovetter (1990) membagi keterlekatan ke dalam dua bentuk, yakni keterlekatan relasional dan keterlekatan struktural. Keterlekatan relasional adalah tindakan ekonomi dengan pengaruh situasi sosial tertentu yang melekat dalam jaringan personal antar para aktor. Antara penjual dan pelanggan terjalin hubungan interpersonal yang melibatkan aspek sosial, budaya, agama, dan politik. Sedangkan yang kedua adalah keterlekatan struktural, yaitu keterlekatan yang melibatkan jaringan yang lebih luas seperti institusi atau struktur sosial. Dalam keterlekatan ini, hubungan terjalin tidak hanya antar individu dalam suatu struktur atau institusi tertentu, melainkan juga pada individu dengan struktur lainnya. Struktur sosial sendiri diartikan sebagai pola interaksi atau hubungan yang yang terorganisir dalam suatu ruang sosial (Damsar, 2011:149).

Adanya keterlekatan struktural dalam tindakan ekonomi di pasar tradisional dapat mendorong terselenggaranya relasi dan jaringan sosial yang tidak hanya sebatas transaksi jual beli, namun lebih merupakan proses yang menampung kebutuhan sosial tertentu. Keterlekatan struktural juga membantu pedagang dan pembeli untuk mendapatkan informasi dan harga komoditas yang wajar agar tidak terjadi informasi yang asimetris dan permainan harga. Di Pasar Pleret sendiri terdapat beberapa permasalahan yang menghambat perkembangan pasar yakni, keberdaan Pasar Modern yang marak berdiri sehingga menimbulkan budaya belanja pembeli yang lebih senang ke pasar modern dari pada pasar tradisional.

Sebenarnya, masalah-masalah di atas dapat terselesaikan, paling tidak diminimalkan, dengan menguatkan ikatan nilai-nilai sosial yang melekat dalam jaringan antar struktur Pasar Pleret. Namun pada kenyataannya, keterlekatan struktural antar struktur di Pasar Pleret sangat lemah sehingga kurang berperan dalam memperjuangkan kepentingan pedagang dan meningkatkan kualitas pasar. Ikatan di antara mereka hanya sebatas interaksi sosial yang belum mengarah pada penguatan kapasitas jaringan struktural. Oleh karena itu, menjadi lumrah jika mereka kurang mampu menyelesaikan persoalan yang berasal dari eksternal mereka.Keterlekatan yang menguat di Pasar Pleret hanya bersifat relasional. Hal ini sebagaimana kasus 
pedagang buah. Pedagang buah di Pasar Pleret tidak mendapatkan dagangannya dari petani langsung, tapi disuplai oleh tengkulak. Padahal harga dari tengkulak sedikit lebih mahal dari pada langsung beli dari petani. Rantai distribusi komoditas itu akan semakin menaikkan harga barang saat sampai pada pembeli. Sistem yang digunakan dalam jual beli buah-buahan ada dua, pertama membayar langsung dagangan yang disuplai, kedua, penyuplai menitipkan barang pada pedagang. Pedagang hanya membayar barang yang terjual. Namun apabila adalah kerusakan pada barang titipan misalnya busuk, pedagang meminta diskon harga meskipun tidak begitu banyak. Itupun terjadi jika mendapat persetujuan penyuplai karena ada juga penyuplai yang tetap minta dibayar sesuai barang yang disuplai.

Sistem pembayarannya sendiri ada dua macam, pertama tunai saat barang sudah disuplai, kedua, pembayaran diserahkan saat barang sudah terjual. Kebanyakan penyuplai menerapkan sistem pembayaran kedua sebagai strategi pemasaran. Ketatnya persaingan pasar menuntut penyuplai harus akomodatif terhadap permintaan pasar, khususnya perlakuan khusus pada pedagang. Keterlekatan relasional ini hanya bermanfaat dalam level individu saja. Namun demikian dapat ditingkatkan dengan dukungan berbagai struktur lainnya di pasar.

Lemahnya keterlekatan struktural di Pasar Pleret terlihat jelas dari belum adanya hubungan sinergis untuk berupaya mengembangkan kualitas pasar. Soliditas pedagang dalam paguyuban belum terbentuk dalam merespon sepinya pengunjung. Masing-masing pedagang masih memikirkan usaha individualnya. Paguyuban hanya difungsikan sebagai sarana peningkatan pendapatan tanpa dikembangkan untuk tujuan yang lebih besar lagi.

Permasalahan lain di Pasar Pleret akibat lemahnya keterlekatan struktural adalah tiadanya fasilitas keuangan dari internal pasar baik bentuk simpanan maupun pinjaman bagi para pedagang. Selama ini para pedagang mengandalkan bank konvesional dari lembaga pemerintah maupun swasta. Dari hasil survei diketahui bahwa mayoritas pedagang yakni 50\% lebih memilih pinjam pada Keluarga. Sedangkan $33,3 \%$ pedagang mengakses pinjaman di Bank.

Dengan lemahnya keterlekatan struktural dalam pasar, keberadaan paguyuban dan pengelola pasar tidak berjalan sebagaimana perannya. Padahal sebanyak 76,6\%,pedagang menganggap keberadaan paguyuban cukup membantu usahanya. Namun pada kenyataannya, Paguyuban hanya digunakan sebagai sarana yang kurang berdampak positif pada dimensi yang lebih luas. Hasil survei menunjukkan bahwa kegiatan di komunitas $38,2 \%$ untuk dipergunakan untuk lain-lain termasuk pengajian, 3,3\% untuk arisan, dan $27,3 \%$ membahas usulan pedagang. Itupun hanya sebesar $63,3 \%$ pedagang yang aktif di paguyuban. Dengan demikian, paguyuban sebagai struktur yang membawahi para pedagang dan sebagai jembatan penghubung antara pengelola dan pedagang menjadi tidak berperan maksimal. Oleh karena itu, penting dan perlu untuk meningkatkan kualitas paguyuban baik secara organisasional maupun ikatannya.

\section{E. Pemetaan Semua Aspek Revitalisasi}

Dari hasil kajian pada aspek lingkungan fisik, aspek ekonomi aspek manajemen dan aspek social, hasilnya dapat dilihat pada table 5.1 berikut ini. 
PEMETAAN ASPEK

REVITALISASI PASAR PLERET

\begin{tabular}{|c|c|c|c|c|c|c|c|c|c|}
\hline $\begin{array}{l}\text { Aspek } \\
\text { Kajian }\end{array}$ & & $\begin{array}{c}\text { Identifikasi } \\
\text { Masalah } \\
\text { Hasil } \\
\text { Observasi }\end{array}$ & & $\begin{array}{c}\text { Diskripsi } \\
\text { Kualitatif } \\
\text { dan } \\
\text { kuantitatif } \\
\text { ( hasil } \\
\text { Survey, } \\
\text { wawancar } \\
\text { a, UGD) }\end{array}$ & & $\begin{array}{c}\text { Arah } \\
\text { Kajian dan } \\
\text { Pemetaan } \\
\text { ( hasil } \\
\text { analisis) }\end{array}$ & & $\begin{array}{c}\text { Arah } \\
\text { /Program } \\
\text { Revitalisasi }\end{array}$ & $\begin{array}{l}\text { Rekomend } \\
\text { asi } \\
\text { Kegiatan }\end{array}$ \\
\hline $\begin{array}{l}\text { Lingkun } \\
\text { gan Fisik }\end{array}$ & $\mathrm{d}$ & $\begin{array}{l}\text { Kondisi } \\
\text { Bangunan: } \\
\text { Lingkungan } \\
\text { dan } \\
\text { Bangunan } \\
\text { Kios/ Los/ } \\
\text { Lapak tidak } \\
\text { berfungsi } \\
\text { maksimal } \\
\text { kerena: } \\
\text { Kios sisi } \\
\text { selatan } \\
\text { pasar tak } \\
\text { terawat dan } \\
\text { tidak } \\
\text { berfungsi } \\
\text { lagi, }\end{array}$ & $\mathrm{d}$ & $\begin{array}{l}\text { Para } \\
\text { pedagang } \\
\text { menyataka } \\
\text { n bangunan } \\
\text { pasar masih } \\
\text { cukup baik } \\
(100 \%) \text {, } \\
\text { tetapi hasil } \\
\text { pantauan, } \\
\text { khusus } \\
\text { bangunan } \\
\text { Kios sisi } \\
\text { selatan } \\
\text { memang } \\
\text { tidak } \\
\text { berfungsi. } \\
\\
\text { Jalur } \\
\text { Sirkulasi } \\
\text { dalam } \\
\text { pasar baik } \\
\text { (100\%) } \\
\text { namun } \\
\text { hasil } \\
\text { pantauan } \\
\text { kurang } \\
\text { teratur dan } \\
\text { nyaman, } \\
\\
\text { Hasil } \\
\text { wawancara, } \\
\text { jika ada } \\
\text { kerusakan } \\
\text { beberapa } \\
\text { pedagang } \\
\text { membenahi }\end{array}$ & $\mathrm{f}$ & $\begin{array}{l}\text { Menjaga } \\
\text { koridor/ } \\
\text { Selasar } \\
\text { tetap } \\
\text { berfungsi } \\
\text { sebagai lalu } \\
\text { lintas } \\
\text { pembeli } \\
\text { akan } \\
\text { memberika } \\
\text { n kepuasan } \\
\text { Kewenanga } \\
\text { n harus } \\
\text { dibarengi } \\
\text { dengan } \\
\text { kemampua } \\
\text { n agar hasil } \\
\text { bisa } \\
\text { maksimal. } \\
\\
\text { Menyiapka } \\
\text { n tempat }\end{array}$ & $\mathrm{e}$ & 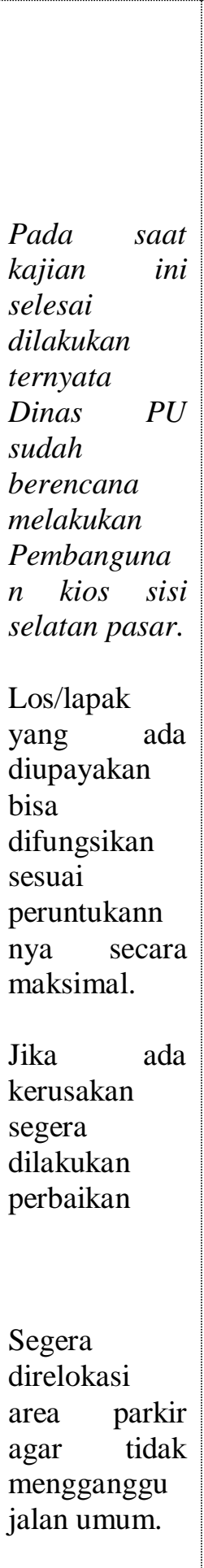 & $\begin{array}{l}\text { Los/lapak } \\
\text { diberikan } \\
\text { kode } \\
\text { nomor/ } \\
\text { identitas } \\
\text { pada sisi } \\
\text { lantai yang } \\
\text { vertikal. } \\
\text { Setiap ada } \\
\text { perbaikan } \\
\text { diupayakan } \\
\text { berkonsulta } \\
\text { si lebih dulu } \\
\text { dg } \\
\text { berwenang. } \\
\text { Dibuatkan } \\
\text { tempat } \\
\text { parkir yang } \\
\text { tepat. }\end{array}$ \\
\hline
\end{tabular}




\begin{tabular}{|c|c|c|c|c|c|c|c|c|c|}
\hline $\begin{array}{l}\text { Aspek } \\
\text { Kajian }\end{array}$ & & $\begin{array}{l}\text { Identifikasi } \\
\text { Masalah } \\
\text { Hasil } \\
\text { Observasi }\end{array}$ & & $\begin{array}{c}\text { Diskripsi } \\
\text { Kualitatif } \\
\text { dan } \\
\text { kuantitatif } \\
\text { ( hasil } \\
\text { Survey, } \\
\text { wawancar } \\
\text { a, UGD) }\end{array}$ & & $\begin{array}{c}\text { Arah } \\
\text { Kajian dan } \\
\text { Pemetaan } \\
\text { ( hasil } \\
\text { analisis) }\end{array}$ & & $\begin{array}{c}\text { Arah } \\
\text { /Program } \\
\text { Revitalisasi }\end{array}$ & $\begin{array}{c}\text { Rekomend } \\
\text { asi } \\
\text { Kegiatan }\end{array}$ \\
\hline & $\mathrm{g}$ & $\begin{array}{l}\text { kendaraan } \\
\text { pengunjung } \\
\text { di sisi } \\
\text { selatan } \\
\text { maupun } \\
\text { utara } \\
\text { menggangg } \\
\text { u fungsi } \\
\text { jalan umum } \\
\text { dan jalan } \\
\text { masuk } \\
\text { pasar. } \\
\text { Drainase } \\
\text { Selatan } \\
\text { Pasar saat } \\
\text { hujan tiba } \\
\text { kurang } \\
\text { berfungsi. } \\
\\
\\
\text { Pagar sisi } \\
\text { utara pasar } \\
\text { terlalu } \\
\text { pendek dan } \\
\text { tak berpintu } \\
\text { sehingga } \\
\text { keamanan } \\
\text { pasar } \\
\text { kurang } \\
\text { terjamin, }\end{array}$ & $\mathrm{g}$ & $\begin{array}{l}\text { sendiri, } \\
\text { hasil } \\
\text { pantauan } \\
\text { perbaikan } \\
\text { kurang } \\
\text { maksimal. } \\
\text { Dari } \\
\text { pantauan, } \\
\text { parkir sisi } \\
\text { selatan dan } \\
\text { sisi utara } \\
\text { yang } \\
\text { menggunak } \\
\text { an bahu } \\
\text { jalan, } \\
\text { membuat } \\
\text { jalan macet } \\
\text { dan } \\
\text { pengunjung } \\
\text { pasar } \\
\text { terganggu. } \\
\\
\text { Masukan } \\
\text { pak Camat, } \\
\text { saat hujan } \\
\text { air masuk } \\
\text { ke dalam } \\
\text { area kantor } \\
\text { kecamatan. }\end{array}$ & $\mathrm{g}$ & $\begin{array}{l}\text { parkir yang } \\
\text { layak itu } \\
\text { merupakan } \\
\text { pelayanan } \\
\text { yang baik. } \\
\\
\text { Drainase } \\
\text { yang baik } \\
\text { mampu } \\
\text { menampun } \\
\text { g air } \\
\text { sebanyak } \\
\text { debit air } \\
\text { yang } \\
\text { terukur. }\end{array}$ & $\mathrm{g}$ & $\begin{array}{l}\text { Dibuatkan } \\
\text { lokasi khusus } \\
\text { TPST } \\
\text { (Tempat } \\
\text { Pengolahan } \\
\text { sampah } \\
\text { Terpadu, } \\
\text { sebelum } \\
\text { dibuang di } \\
\text { TPA. }\end{array}$ & $\begin{array}{l}\text { harus } \\
\text { berdasar } \\
\text { ukuran } \\
\text { besarnya air } \\
\text { yang akan } \\
\text { melewati, } \\
\text { harus ada } \\
\text { perhitungan } \\
\text { yang benar. } \\
\text { Segera } \\
\text { diupayakan } \\
\text { pembangun } \\
\text { an Pagar } \\
\text { pasar pleret } \\
\text { sisi utara } \\
\text { dengan } \\
\text { desain lebih } \\
\text { tinggi, } \\
\text { berpintu, } \\
\text { transparan } \\
\text { dengan } \\
\text { memperhati } \\
\text { kan estetika } \\
\text { dan } \\
\text { kekhasan } \\
\text { pleret. } \\
\text { Pengelola } \\
\text { pasar } \\
\text { sebaiknya } \\
\text { berembug } \\
\text { bersama } \\
\text { dengan } \\
\text { Dinas BLH } \\
\text { untuk } \\
\text { mencarikan } \\
\text { jalan keluar } \\
\text { yang baik } \\
\text { perihal } \\
\text { pengelolaan } \\
\text { sampah. }\end{array}$ \\
\hline
\end{tabular}




\begin{tabular}{|c|c|c|c|c|c|c|c|c|c|}
\hline $\begin{array}{l}\text { Aspek } \\
\text { Kajian }\end{array}$ & & $\begin{array}{c}\text { Identifikasi } \\
\text { Masalah } \\
\text { Hasil } \\
\text { Observasi }\end{array}$ & & $\begin{array}{c}\text { Diskripsi } \\
\text { Kualitatif } \\
\text { dan } \\
\text { kuantitatif } \\
\text { ( hasil } \\
\text { Survey, } \\
\text { wawancar } \\
\text { a, UGD) }\end{array}$ & & $\begin{array}{c}\text { Arah } \\
\text { Kajian dan } \\
\text { Pemetaan } \\
\text { ( hasil } \\
\text { analisis) }\end{array}$ & & $\begin{array}{c}\text { Arah } \\
\text { /Program } \\
\text { Revitalisasi }\end{array}$ & $\begin{array}{l}\text { Rekomend } \\
\text { asi } \\
\text { Kegiatan }\end{array}$ \\
\hline & & & & $\begin{array}{l}\text { Sebaiknya } \\
\text { sampah } \\
\text { sudah ada } \\
\text { pemisahan } \\
\text { antara } \\
\text { sampah un- } \\
\text { organik dan } \\
\text { organik, } \\
\text { dan } \\
\text { memerluka } \\
\text { n tempat } \\
\text { khusus } \\
\text { penampung } \\
\text { sementara } \\
\text { menurut } \\
\text { BLH. }\end{array}$ & & & & & \\
\hline Ekonomi & $\mathrm{b}$ & $\begin{array}{l}\text { Berdagang } \\
\text { satu satunya } \\
\text { mata } \\
\text { pencaharian } \\
\text { nya. } \\
\text { Mereka } \\
\text { hanya } \\
\text { penjual } \\
\text { antara, hasil } \\
\text { produksi } \\
\text { sendiri } \\
\text { hanya } \\
\text { terbatas. } \\
\end{array}$ & $\mathrm{b}$ & $\begin{array}{l}\text { Alasan } \\
\text { responden } \\
\text { sebanyak } \\
100 \% \\
\text { berdagang } \\
\text { karena } \\
\text { hanya itu } \\
\text { peluang } \\
\text { hidupnya. } \\
\text { Sumber } \\
\text { barang } \\
\text { berasal dari } \\
\text { grosir } \\
\text { sebanyak } \\
53,3 \% \text {, dan } \\
\text { barang } \\
\text { titipan } \\
30 \% \\
\text { artinya } \\
\text { harga dan } \\
\text { keuntungan } \\
\text { dari } \\
\text { pedagang }\end{array}$ & $\mathrm{b}$ & $\begin{array}{l}\text { Memberi } \\
\text { kemudahan } \\
\text { dan fasilitas } \\
\text { yang layak } \\
\text { akan } \\
\text { memotivasi } \\
\text { pedagang } \\
\text { bekerja } \\
\text { lebih baik. } \\
\text { Membeli } \\
\text { dalam } \\
\text { jumlah } \\
\text { besar akan } \\
\text { memperole } \\
\text { h potongan } \\
\text { harga lebih } \\
\text { besar pula, } \\
\text { artinya } \\
\text { lebih } \\
\text { mudah } \\
\text { memainkan } \\
\text { harga untuk } \\
\text { menang }\end{array}$ & $\mathrm{b}$ & $\begin{array}{l}\text { Dilakukan } \\
\text { pendataan } \\
\text { ulang } \\
\text { pedagang dan } \\
\text { area } \\
\text { (Kios/Los/La } \\
\text { pak). } \\
\text { Organisasi } \\
\text { Komunitas } \\
\text { harus dirintis } \\
\text { menjadi } \\
\text { pengganti } \\
\text { Distributor/gr } \\
\text { osir barang di } \\
\text { pasar. } \\
\\
\\
\text { Diupayakan } \\
\text { adanya } \\
\text { sumber modal } \\
\text { yang }\end{array}$ & $\begin{array}{l}\text { Setiap } \\
\text { Kios/Los/La } \\
\text { pak diberi } \\
\text { surat } \\
\text { keterangan } \\
\text { hak } \\
\text { pemanfaata } \\
\text { n. } \\
\\
\text { Buat } \\
\text { organisasi } \\
\text { yang } \\
\text { dilindungi } \\
\text { hukum agar } \\
\text { memiliki } \\
\text { kekuatan } \\
\text { tawar } \\
\text { menawar } \\
\text { dengan } \\
\text { produsen. }\end{array}$ \\
\hline
\end{tabular}




\begin{tabular}{|c|c|c|c|c|c|c|c|c|c|}
\hline $\begin{array}{l}\text { Aspek } \\
\text { Kajian }\end{array}$ & & $\begin{array}{c}\text { Identifikasi } \\
\text { Masalah } \\
\text { Hasil } \\
\text { Observasi }\end{array}$ & & $\begin{array}{c}\text { Diskripsi } \\
\text { Kualitatif } \\
\text { dan } \\
\text { kuantitatif } \\
\text { ( hasil } \\
\text { Survey, } \\
\text { wawancar } \\
\text { a, UGD) }\end{array}$ & & $\begin{array}{c}\text { Arah } \\
\text { Kajian dan } \\
\text { Pemetaan } \\
\text { ( hasil } \\
\text { analisis) }\end{array}$ & & $\begin{array}{c}\text { Arah } \\
\text { /Program } \\
\text { Revitalisasi }\end{array}$ & $\begin{array}{l}\text { Rekomend } \\
\text { asi } \\
\text { Kegiatan }\end{array}$ \\
\hline & $\mathrm{e}$ & $\begin{array}{l}\text { Perkembang } \\
\text { an usaha } \\
\text { berjalan } \\
\text { lambat, } \\
\text { bahkan } \\
\text { terkadang } \\
\text { naik dan } \\
\text { terkadang } \\
\text { turun, }\end{array}$ & $\mathrm{e}$ & $\begin{array}{l}\text { Dari hasil } \\
\text { survey para } \\
\text { pedang } \\
\text { memiliki } \\
\text { modal } \\
\text { sendiri } \\
\text { sebanyak } \\
73,3 \% \text { dan } \\
\text { pinjam } \\
\text { Bank 20\%, } \\
\text { dan jika } \\
\text { butuh } \\
\text { tambahan } \\
\text { modal, } \\
\text { pinjam } \\
\text { Keluarga } \\
\text { dan bank }\end{array}$ & $\mathrm{d}$ & $\begin{array}{l}\text { bersaing } \\
\\
\text { Saat } \\
\text { seseorang } \\
\text { Memerluka } \\
\text { n Modal } \\
\text { Usaha } \\
\text { maka akan } \\
\text { menjadi } \\
\text { sasaran } \\
\text { empuk para } \\
\text { pemilik } \\
\text { modal } \\
\text { dengan } \\
\text { beban } \\
\text { resiko } \\
\text { apapun. } \\
\\
\text { Persaingan } \\
\text { sempurna } \\
\text { itu ada di } \\
\text { pasar, } \\
\text { sedangkan } \\
\text { menaikkan } \\
\text { kualitas } \\
\text { berdagang } \\
\text { itu ada } \\
\text { pada sikap } \\
\text { dan } \\
\text { perilaku } \\
\text { personal } \\
\text { pedagang } \\
\text { dan } \\
\text { pemilihan } \\
\text { barang } \\
\text { dagangann } \\
\text { ya. }\end{array}$ & $\mathrm{e}$ & $\begin{array}{l}\text { memberikan } \\
\text { kemudahan } \\
\text { bagi para } \\
\text { pedagang. } \\
\text { Menciptakan } \\
\text { persaingan } \\
\text { sempurna di } \\
\text { pasar, } \\
\text { pelayanan } \\
\text { yang baik } \\
\text { oleh } \\
\text { pedagang dan } \\
\text { pemisahan } \\
\text { barang } \\
\text { dagang antara } \\
\text { yang baik dan } \\
\text { kurang baik, } \\
\text { akan } \\
\text { memberikan } \\
\text { kenyamanan } \\
\text { pembeli. } \\
\\
\text { Mengupayaka } \\
\text { n area yang } \\
\text { bisa } \\
\text { dimanfaatkan } \\
\text { oleh produsen } \\
\text { melalui } \\
\text { suplayernya } \\
\text { untuk } \\
\text { kegiatan } \\
\text { promosi. }\end{array}$ & $\begin{array}{l}\text { Pengaturan } \\
\text { secara } \\
\text { Zonasi akan } \\
\text { menciptaka } \\
\mathrm{n} \\
\text { persaingan } \\
\text { sempurna, } \\
\text { para pedang } \\
\text { akan lebih } \\
\text { berfokus } \\
\text { pada } \\
\text { pelayanan } \\
\text { yang baik. }\end{array}$ \\
\hline
\end{tabular}




\begin{tabular}{|c|c|c|c|c|c|c|c|c|c|}
\hline $\begin{array}{l}\text { Aspek } \\
\text { Kajian }\end{array}$ & & $\begin{array}{c}\text { Identifikasi } \\
\text { Masalah } \\
\text { Hasil } \\
\text { Observasi }\end{array}$ & & $\begin{array}{c}\text { Diskripsi } \\
\text { Kualitatif } \\
\text { dan } \\
\text { kuantitatif } \\
\text { ( hasil } \\
\text { Survey, } \\
\text { wawancar } \\
\text { a, UGD) }\end{array}$ & & $\begin{array}{c}\text { Arah } \\
\text { Kajian dan } \\
\text { Pemetaan } \\
\text { ( hasil } \\
\text { analisis) }\end{array}$ & & $\begin{array}{c}\text { Arah } \\
\text { /Program } \\
\text { Revitalisasi }\end{array}$ & $\begin{array}{c}\text { Rekomend } \\
\text { asi } \\
\text { Kegiatan }\end{array}$ \\
\hline & & & & $\begin{array}{l}\text { penghamba } \\
\mathrm{t} \text { ada } 60 \% \\
\text { menyataka } \\
\mathrm{n} \text { adanya } \\
\text { pengelolaa } \\
\mathrm{n} \text { pasar } \\
\text { modern } \\
\text { yang lebih } \\
\text { berkualitas } \\
\text { dan } \\
\text { bersaing } \\
\text { tidak sehat } \\
\text { antar } \\
\text { pedagang } \\
23 \% \text {, } \\
\text { Banyak } \\
\text { barang } \\
\text { dagangan } \\
\text { baru yang } \\
\text { perlu } \\
\text { pengenalan } \\
\text { kepada } \\
\text { pembeli. }\end{array}$ & & $\begin{array}{l}\text { pedagang } \\
\text { dalam hal } \\
\text { promosi } \\
\text { terutama } \\
\text { pada } \\
\text { dagangan } \\
\text { baru. }\end{array}$ & & & \\
\hline $\begin{array}{l}\text { Manaje } \\
\text { men }\end{array}$ & $a$ & $\begin{array}{l}\text { SulitMengat } \\
\text { ur Pedagang } \\
\text { secara } \\
\text { zonasi }\end{array}$ & $\mathrm{a}$ & $\begin{array}{l}\text { kantor } \\
\text { pengelolaa } \\
\mathrm{n} \text { pasar } \\
\text { sudah } \\
\text { berupaya } \\
\text { melaksanak } \\
\text { an zonasi } \\
\text { berdasar } \\
\text { jenis } \\
\text { barang } \\
\text { dagangan } \\
\\
\text { Data } \\
\text { responden } \\
80 \% \\
\text { menyetujui } \\
\text { jika } \\
\text { pedagang } \\
\text { ditata } \\
\text { secara }\end{array}$ & $\mathrm{a}$ & $\begin{array}{l}\text { Pengaturan } \\
\text { Zonasi } \\
\text { meningkatk } \\
\text { an layanan } \\
\text { terhadap } \\
\text { pembeli } \\
\text { dan } \\
\text { menghilang } \\
\text { kan } \\
\text { persaingan } \\
\text { yang } \\
\text { kurang } \\
\text { sehat. } \\
\\
\text { Koperasi }\end{array}$ & $a$ & $\begin{array}{l}\text { Lakukan } \\
\text { seperti pada } \\
\text { kolom } \\
\text { rekomendasi } \\
\text { Aspek } \\
\text { lingkungan } \\
\text { fisik (poin b.) } \\
\text { Di atas } \\
\text { kemudian } \\
\text { lihat pada } \\
\text { aspek } \\
\text { ekonomi pada } \\
\text { kolom Arah } \\
\text { dan } \\
\text { Rekomendasi } \\
\text { aspek } \\
\text { Ekonomi } \\
\text { (point. a ) }\end{array}$ & $\begin{array}{l}\text { Langkah } \\
\text { awal } \\
\text { Kios/Los/La } \\
\text { pak } \\
\text { dibuatkan } \\
\text { tulisan yang } \\
\text { sesuai } \\
\text { dengan } \\
\text { kelompok } \\
\text { dagangan } \\
\text { dan } \\
\text { gantungkan } \\
\text { pada tempat } \\
\text { yang mudah } \\
\text { dilihat. } \\
\text { (persis } \\
\text { tulisan yang } \\
\text { ada di Lotte } \\
\text { Mart, } \\
\text { superindo }\end{array}$ \\
\hline
\end{tabular}




\begin{tabular}{|c|c|c|c|c|c|c|c|c|c|}
\hline $\begin{array}{c}\text { Aspek } \\
\text { Kajian }\end{array}$ & & $\begin{array}{c}\text { Identifikasi } \\
\text { Masalah } \\
\text { Hasil } \\
\text { Observasi }\end{array}$ & & $\begin{array}{c}\text { Diskripsi } \\
\text { Kualitatif } \\
\text { dan } \\
\text { kuantitatif } \\
\text { ( hasil } \\
\text { Survey, } \\
\text { wawancar } \\
\text { a, UGD) }\end{array}$ & & $\begin{array}{c}\text { Arah } \\
\text { Kajian dan } \\
\text { Pemetaan } \\
\text { ( hasil } \\
\text { analisis) }\end{array}$ & & $\begin{array}{c}\text { Arah } \\
\text { /Program } \\
\text { Revitalisasi }\end{array}$ & $\begin{array}{c}\text { Rekomend } \\
\text { asi } \\
\text { Kegiatan }\end{array}$ \\
\hline & $\mathrm{e}$ & $\begin{array}{l}\text { Belum } \\
\text { memahami } \\
\text { adanya } \\
\text { manfaat } \\
\text { Koperasi } \\
\text { berbadan } \\
\text { hukum dan } \\
\text { profeional }\end{array}$ & $\mathrm{d}$ & $\begin{array}{l}\text { Dari } \\
\text { paguyuban } \\
\text { pedagang } \\
\text { dipilih } \\
\text { menjadi } \\
\text { pengelola } \\
\text { koperasi } \\
\text { yang sudah } \\
\text { berbadan } \\
\text { hukum, ini } \\
\text { dimungkin } \\
\text { kan karena } \\
100 \% \\
\text { pedagang } \\
\text { sangat } \\
\text { setuju. }\end{array}$ & e & $\begin{array}{l}\text { Pemanfaata } \\
\mathrm{n} \text { waktu } \\
\text { operasional } \\
12 \text { hari } \\
\text { dalam } \\
\text { sebulan } \\
\text { (jika buka } \\
\text { hanya pada } \\
\text { pasaran } \\
\text { Pon dan } \\
\text { Kliwon) } \\
\text { dibanding } \\
\text { dengan } 30 \\
\text { hari } \\
\text { sebulan } \\
\text { akan } \\
\text { berdampak } \\
\text { pada hasil } \\
\text { produksi. } \\
\\
\text { Membuang } \\
\text { sampah } \\
\text { pada } \\
\text { tempat } \\
\text { yang } \\
\text { disediakan } \\
\text { akan } \\
\text { membantu } \\
\text { kebersihan } \\
\text { area pasar. }\end{array}$ & $\mathrm{e}$ & \begin{tabular}{l} 
Pengelolaan \\
Koperasi \\
secara \\
profesional \\
akan \\
membantu \\
kantor \\
Pengelola \\
Pasar pada \\
semua aspek \\
seperti \\
pemeliharaan \\
fasilitas, \\
penyediaan \\
sumber dana, \\
sumber \\
barang \\
dagangan dan \\
lainnya. \\
Pasar por pon \\
operasional \\
buka setiap \\
hari dan \\
khusus pada \\
pasaran pon \\
dan kliwon \\
dibuatkan \\
event khusus \\
untuk tetap \\
melestarikan \\
budaya \\
pasaran pon \\
dan kliwon. \\
\multicolumn{1}{c}{ Diupayakan } \\
ada kegiatan \\
peninjauan \\
mendadak \\
oleh kantor \\
pengelola \\
pasar bersama \\
dengan \\
pengurus \\
paguyuban,
\end{tabular} & $\begin{array}{l}\text { Pasar } \\
\text { tradisional } \\
\text { dipusatkan } \\
\text { di Pleret, } \\
\text { sedangkan } \\
\text { pasar } \\
\text { Jejeran akan } \\
\text { menjadi } \\
\text { area pasar } \\
\text { baru untuk } \\
\text { relokasi } \\
\text { pasar } \\
\text { klitikan, } \\
\text { barang } \\
\text { bekas dan } \\
\text { pusat alat } \\
\text { elektronika. } \\
\\
\text { Disetiap } \\
\text { sarana } \\
\text { TPST } \\
\text { (Tempat } \\
\text { Pengelolaan } \\
\text { Sampah } \\
\text { Terpadu) }\end{array}$ \\
\hline
\end{tabular}




\begin{tabular}{|c|c|c|c|c|c|c|c|c|c|}
\hline $\begin{array}{c}\text { Aspek } \\
\text { Kajian }\end{array}$ & & $\begin{array}{l}\text { Identifikasi } \\
\text { Masalah } \\
\text { Hasil } \\
\text { Observasi }\end{array}$ & & $\begin{array}{c}\text { Diskripsi } \\
\text { Kualitatif } \\
\text { dan } \\
\text { kuantitatif } \\
\text { ( hasil } \\
\text { Survey, } \\
\text { wawancar } \\
\text { a, UGD) }\end{array}$ & & $\begin{array}{c}\text { Arah } \\
\text { Kajian dan } \\
\text { Pemetaan } \\
\text { ( hasil } \\
\text { analisis) }\end{array}$ & & $\begin{array}{c}\text { Arah } \\
\text { /Program } \\
\text { Revitalisasi }\end{array}$ & $\begin{array}{c}\text { Rekomend } \\
\text { asi } \\
\text { Kegiatan }\end{array}$ \\
\hline & & & & $\begin{array}{l}\text { Dinas } \\
\text { Perindakop } \\
\text { Bantul } \\
\text { menyampai } \\
\text { kan bahwa } \\
\text { koperasi } \\
\text { harus yang } \\
\text { berbadan } \\
\text { hukum. } \\
\text { Para } \\
\text { pedagang } \\
\text { setuju jika } \\
\text { semua } \\
\text { pedagang } \\
\text { wajib } \\
\text { menjadi } \\
\text { anggota } \\
\text { koperasi. }\end{array}$ & & $\begin{array}{l}\text { Koperasi } \\
\text { berbadan } \\
\text { hukum } \\
\text { akan } \\
\text { menjadi } \\
\text { bemper } \\
\text { utama bagi } \\
\text { para } \\
\text { pedagang } \\
\text { sebagai } \\
\text { anggotanya } \\
\text { Para } \\
\text { anggota } \\
\text { mempunyai } \\
\text { hak dan } \\
\text { kuajiban. }\end{array}$ & & $\begin{array}{l}\text { meneliti } \\
\text { tentang } \\
\text { kebersihan } \\
\text { area. } \\
\text { Para } \\
\text { pedagang } \\
\text { harus } \\
\text { mempunyai } \\
\text { simpanan di } \\
\text { wajib di di } \\
\text { koperasi yang } \\
\text { besarnya } \\
\text { ditentukan } \\
\text { sama tiap } \\
\text { anggota. Dan } \\
\text { mempunyai } \\
\text { simpanan } \\
\text { sukarela yang } \\
\text { besarnya bisa } \\
\text { berbeda. }\end{array}$ & $\begin{array}{l}\text { diberi } \\
\text { tulisan } \\
\text { buang } \\
\text { sampah } \\
\text { pada } \\
\text { tempatnya. } \\
\\
\\
\text { Kantor } \\
\text { Pengelola } \\
\text { pasar } \\
\text { bersama } \\
\text { Perindakop } \\
\text { selalu } \\
\text { memonitor } \\
\text { pengelolaan } \\
\text { Koperasi } \\
\text { menuju } \\
\text { pengelolaan } \\
\text { yang } \\
\text { profesional. }\end{array}$ \\
\hline Sosial & $\mathrm{b}$ & $\begin{array}{l}\text { Interaksi } \\
\text { antar } \\
\text { pedagang } \\
\text { intensif dan } \\
\text { baik tetapi } \\
\text { belum } \\
\text { masuk ke } \\
\text { ranah } \\
\text { usahanya. }\end{array}$ & $\mathrm{b}$ & $\begin{array}{l}\text { Sebesar } \\
76,7 \% \\
\text { antar } \\
\text { pedagang } \\
\text { sering } \\
\text { berinteraksi } \\
\text { dan pokok } \\
\text { bahasan } \\
\text { terbanyak } \\
\text { pada hal } \\
\text { biasa yaitu } \\
\text { tentang } \\
\text { keluarga, } \\
\text { sedangkan } \\
\text { tentang } \\
\text { kondisi } \\
\text { pasar dan } \\
\text { harga, } \\
\text { masih } \\
\text { terbatas. }\end{array}$ & $b$ & $\begin{array}{l}\text { Area } \\
\text { berdagang } \\
\text { yang belum } \\
\text { terkelompo } \\
\mathrm{k} \quad \text { sesuai } \\
\text { jenis } \\
\text { dagangann } \\
\text { ya akan } \\
\text { menghamb } \\
\text { at informasi } \\
\text { khusus } \\
\text { yang } \\
\text { dibutuhkan } \\
\text { masing } \\
\text { masing } \\
\text { pedagang. } \\
\text { Interaksi } \\
\text { intensif } \\
\text { antara } \\
\text { Pembeli } \\
\text { dan }\end{array}$ & $\mathrm{b}$ & $\begin{array}{l}\text { Mengelompo } \\
\text { kkan } \\
\text { pedagang } \\
\text { sejenis agar } \\
\text { antar } \\
\text { pedagang saat } \\
\text { berinteraksi } \\
\text { pokok } \\
\text { bahasannya } \\
\text { lebih banyak } \\
\text { menjurus } \\
\text { pada usaha } \\
\text { dagangannya. } \\
\\
\text { Pelayanan } \\
\text { oleh } \\
\text { pedagang } \\
\text { lebih } \\
\text { ditingkatkan } \\
\text { lagi agar } \\
\text { pengunjung }\end{array}$ & $\begin{array}{l}\text { Penguatan } \\
\text { interaksi } \\
\text { pedagang } \\
\text { yang sejenis } \\
\text { agar } \\
\text { terhindar } \\
\text { persaingan } \\
\text { yang kurang } \\
\text { sehat. }\end{array}$ \\
\hline
\end{tabular}




\begin{tabular}{|c|c|c|c|c|c|c|c|}
\hline $\begin{array}{l}\text { Aspek } \\
\text { Kajian }\end{array}$ & & $\begin{array}{l}\text { Identifikasi } \\
\text { Masalah } \\
\text { Hasil } \\
\text { Observasi }\end{array}$ & \begin{tabular}{|c} 
Diskripsi \\
Kualitatif \\
dan \\
kuantitatif \\
( hasil \\
Survey, \\
wawancar \\
a, UGD)
\end{tabular} & & $\begin{array}{c}\text { Arah } \\
\text { Kajian dan } \\
\text { Pemetaan } \\
\text { ( hasil } \\
\text { analisis) }\end{array}$ & $\begin{array}{c}\text { Arah } \\
\text { /Program } \\
\text { Revitalisasi }\end{array}$ & $\begin{array}{c}\text { Rekomend } \\
\text { asi } \\
\text { Kegiatan }\end{array}$ \\
\hline & $\mathrm{c}$ & $\begin{array}{l}\text { karena } \\
\text { hanya buka } \\
\text { dua hari saja } \\
\text { dalam } \\
\text { seminggu } \\
\\
\text { Struktur } \\
\text { social yang } \\
\text { terikat baru } \\
\text { hanya } \\
\text { penjual dan } \\
\text { pembeli, } \\
\text { yang } \\
\text { pengelola } \\
\text { serta } \\
\text { paguyuban } \\
\text { hanya } \\
\text { sebatas } \\
\text { interaksi } \\
\text { saja. }\end{array}$ & $\begin{array}{l}\text { Data } \\
\text { menunjukk } \\
\text { an } 42,5 \% \\
\text { pembeli } \\
\text { menyataka } \\
\text { n kenal saja } \\
\text { dengan } \\
\text { pedagang } \\
\text { dan } 30 \% \\
\text { menyataka } \\
\text { n kenal } \\
\text { dekat } \\
\text { Data } \\
\text { menunjukk } \\
\text { an } \\
\text { hubungan } \\
\text { pedagang } \\
\text { dengan } \\
\text { pengelola } \\
\text { adalah } \\
\text { penting } \\
\text { sebanyak } \\
76,7 \% \text { dan } \\
\text { ada yang } \\
\text { menyataka } \\
n \text { sangat } \\
\text { penting } \\
16,7 \quad \% \\
\text { dan di atas } \\
60 \% \\
\text { menyataka } \\
n \text { kenal } \\
\text { dengan } \\
\text { pengelola }\end{array}$ & $\mathrm{c}$ & $\begin{array}{l}\text { pedagang } \\
\text { sehingga } \\
\text { menjadi } \\
\text { kenal lebih } \\
\text { dekat akan } \\
\text { memberika } \\
\text { n kepuasan } \\
\text { bagi } \\
\text { keduanya. } \\
\text { Data } \\
\text { menunjuka } \\
\text { n bahwa } \\
\text { pengelola } \\
\text { bisa lebih } \\
\text { dekat } \\
\text { dengan } \\
\text { pedagang } \\
\text { yang } \\
\text { artinya } \\
\text { secara } \\
\text { personal } \\
\text { bisa } \\
\text { mencari } \\
\text { tahu } \\
\text { permasalah } \\
\text { an yang } \\
\text { dihadapiny } \\
\text { a. }\end{array}$ & $\begin{array}{l}\text { puas dan tetap } \\
\text { berlangganan. } \\
\\
\text { Intensitas } \\
\text { pertemuan } \\
\text { para } \\
\text { pedagang } \\
\text { akan menjadi } \\
\text { sarana kontrol } \\
\text { yang sangat } \\
\text { baik bagi } \\
\text { kantor } \\
\text { pengelola } \\
\text { pasar. }\end{array}$ & $\begin{array}{l}\text { Organisasi } \\
\text { Komunitas } \\
\text { Paguyuban } \\
\text { Pedagang) } \\
\text { harus lebih } \\
\text { berperan } \\
\text { aktif } \\
\text { terhadap } \\
\text { permasalaha } \\
\text { n yang } \\
\text { dihadapi } \\
\text { pedagang } \\
\text { dan selalu } \\
\text { dikonsultasi } \\
\text { kan kepada } \\
\text { pengelola } \\
\text { pasar. }\end{array}$ \\
\hline
\end{tabular}

KESIMPULAN DAN REKOMENDASI

Berdasarkan analisa dan pembahasan pada bab sebelumnya dapat diambil beberapa kesimpulan sebagai berikut di bawah ini.

Pasar Pleret merupakan salah satu pasar tradisional yang cukup ramai di Kabupaten Bantul, terletak di lokasi strategis yakni di Dusun Kauman, Desa Pleret, Kecamatan Pleret. Pasar ini masuk kategori kelas II dengan luas tanah \pm $6.150 \mathrm{~m}^{2}$ dan merupakan tanah Pemerintah. Pasar ini dilengkapi dengan fasilitas tempat parkir, tempat ibadah, kantor pengelola, KM/WC, sarana pengelolaan kebersihan, 
sarana pengamanan, sarana air bersih, instalasi listrik, penerangan umum

Berdasarkan hasil obeservasi, bahwa pasar Pleret hanya buka pada saat 'pasaran' Pon atau Kliwon. Jadi dalam sebulan pasar operasional buka hanya 12 hari saja.Terdaftar sebanyak 514 pedagang berjualan pada saat pasar buka. Hari yang lain para pedagang buka kios/los/lapak di pasar Jejeran. Dari hasil kajian dapat daiambil kesimpulan berdasar Aspek Lingkungan Fisik, Ekonomi, Manajemen dan Sosial.

1. Berdasarkan hasil survey ada beberapa isu penting terkait dengan penataan lingkungan fisik Pasar Pleret, diantaranya perombakan wajah pasar Pleret, penataan pedagang di Selasar/koridor Los pasar, dan penataan akses masuk Pasar Pleret dengan mencarikan solusi tempat parkir kendaraan yang aman dan tidak mengganggu lalu lintas jalan.

2. Masalah parkir ini berhubungan dengan aksesibiltas eksternal bagi pedagang maupun pengunjung, disamping aspek keamanan dan kenyamanannya. Masalah lain yang juga menunggu perhatian adalah pengelolaan sampah perlu penanganan serius dan perbaikan drainase terutama disisi selatan pasar. Rencana perubahan wajah pasar harus bisa memunculkan kesan Khas Budaya pasar leret yang berbentuk unik sebagai salah satu cagar Budaya di Pleret.

3. Perlu disediakan area untuk publik khususnya untuk warga masyarakat sekitar guna kegiatan sosial kemasyarakatan, oleh raga dan seni budaya dan pembuatan area kuliner khas Kabupaten Bantul sekaligus sebagai pusat oleh-oleh untuk menyemarakkan pasar Pleret dan mendukung Kawasan wisata kuliner di pleret.

4. Kehadiran pasar modern dan ketatnya persaingan antar pedagang, sumber permodalan mempengaruhi kondisi usaha para pedagang.

5. Kantor Pengelola pasar harus memiliki mitra untuk membantu mengelola pasar sebagai perwujudan kemandirian usaha para pedagang yaitu dengan mengoptimalkan organisasi dengan membangun koperasi berbadan hukum.

6. Di dalam Pasar Pleret berkembang nilai dan norma sosial budaya yang mewarnai proses sosial sehari-hari, diantaranya adalah solidaritas, gotong royong, toleransi dan kepercayaan yang bisa melengkapi dan menjadi modal non uang.

7. Sebagai pasar tradisional, Pasar Pleret secara struktural memiliki empat unsur struksur sosial, yakni kantorpengelola pasar, paguyuban pedagang, para pedagang dan para pembeli. Interaksi sosial antar unsur tersebut termasuk kuat dan terlihat dari jalinan komunikasi di antara mereka. Kekuatan interaksi ini merupakan modal yang penting untuk peningkatan pertumbuhan Pasar Pleret ke depan.

\section{A. Rekomendasi Revitalisasi Pasar Pleret}

1. Akses masuk Pasar Pleret bisa dibuat dari segala penjuru, namun demikian diupayakan pada saat pasar tidak operasional maka keamanan barang milik pedagang harus terjamin. Untuk itu pagar sisi utara pasar bisa dibangun lebih tinggi dengan desain, aman transparan dan berestetika 
sesuai tradisi budaya pleret. Semua akses masuk diberi pintu sebagai ujud penghormatan karena di dalam pasar ada Los pasar yang dilindungi Balai Cagar Budaya. Selain itu perlu disediakan area yang bisa digunakan untuk aktivitas umum, seperti Kegiatan Pameran atau even tertentu, promosi dll.

2. Masalah Perparkiran terutama yang menggunakan bahu jalan di sisi selatan dan bahu jalan di sisi utara pasar segera direlokasi dengan menyediakan lahan parkir yang tepat.

3. Ada Pemberhentian khusus untuk bongkar muat barang barang dagangan,

4. Disediakan sarana Pengelolaan sampah pada lokasi khusus/ TPST (Tempat Pengelolaan Sampah Terpadu)sebelum dibuang ke Tempat Pembuangan Akhir. Pengelolaan Sampah ini akan menjadi bahasan khusus antara Kantor Pengelola Pasar dengan BLH.

5. Segera dilakukan perbaikan Drainase terutama disisi selatan pasar.

6. Sejalan dengan penataan pasar dari kesan kumuh, semua koridor yang membelah Los pasar, harus dibersihkan dari para pedagang, sehingga hilir mudik pedagang dan pembeli lebih nyaman.

7. Para Pedagang diatur secara Zonasi, minimal dipisahkan antara bagian kering (kelontong dan sejenisnya) dan bagian basah (sayur-sayuran dan daging/ikan) Tidak ada lagi kendaraan roda dua yang boleh melintas di area dalam pasar. Tumpukan barang dagangan juga dilarang berada di area koridor tersebut. . Dengan demikian kesan Pasar Pleret sebagai Pasar Tradisional yang modern akan terjadi. Dinas pengelola pasar disarankan untuk selalu mengkampanyekan pada para pedagang, pengunjung dan masyarakat umum lainnya sebuah jargon Pasar Pleret sebagai Pasar Tradisional Modern dan Pusat Kuliner Bantul. Dengan demikian secara bertahap dilakukan pembenahan pada bentuk los dan kios menuju pasar tradisional yang modern dan Pusat Kuliner.

8. Pemberdayaan Pasar Pleret, merupakan segala upaya pemerintah daerah dalam melindungi keberadaan pasar tradisonal agar mampu berkembang lebih baik untuk dapat bersaing dengan pusat perbelanjaan dan toko modern melalui upayaupaya berkesinambungan terhadap:

- Peningkatan kompetensi pedagang melalui wadah Paguyuban Pedagang.

- Mengupayakan agar para pedagang terbiasa dengan lingkungan yang bersih, tertib dan rapi.

- Kantor Pengelola Pasar menjadi fasilitator dan motivator bagi Paguyuban Pedagang dalam merintis Koperasi berbadan hukum.

- Peningkatan kualitas dan pembenahan sarana fisik dasar;

- Mengatur Kios/Los/Lapak dengan memberi identitas hak pemanfaatan dan peruntukannya agar mudah dilakukan zonasi.

9. Pengembangan produk unggulan yang menjadi ciri khas atau keunikan dari Pasar Pleret yang tidak dijumpai di Pasar-Pasar Tradisonal lainnya sehingga dapat 
memberi nilai tambah dan daya tarik bagi masyarakat untuk datang berkunjung.

- Pusat Oleh oleh Kas Bantul seperti Geplak, Peyek Tumpuk, Sagon Basah dll.

- Pusat Kuliner seperti : Sate klatak, sate sapi, Bakmi Jowo dll.

10. Penguatan aspek pemasaran secara terintegrasi untuk meningkatkan citra atau image Pasar Pleret

11. Meningkatkan Produktivitas pasar dengan :

- Berubah menjadi pasar normal, artinya buka pada semua 'pasaran' dengan tetap mempertahankan ciri pada Pasaran Pon dan Pasaran Kliwon, dengan even even tertentu.

Keuntungan apabila pasar pleret berubah menjadi pasar normal:

1) Aktivitas usaha pedagang bisa terfokus di Pasar Pleret selama 30 hari penuh.

2) Jam Operasional akan sangat bervariasi dan bisa jadi dari pagi sampai dengan sore akan selalu ada aktivitas usaha, hal ini dimungkinkan mengingat jenis usaha pedagang sangat bervariasi.

3) Karena pasar pleret mudah dijangkau dan di lokasi Pasar Pleret masih sedikit berdiri pasar modern maka pengunjung tetap akan ramai di siang dan sore hari.

4) Pasar jejeran bisa digunakan sebagai 'pasar baru' untuk merelokasi pasar Klitikan yang tidak jauh dari pasar jejeran, bisa juga pusat/grosir elektronik dan lainnya.

5) Memposisikan Koperasi Pasar sebagai tulang punggung pasar.
6) Memposisikan Paguyuban Pedagang sebagai organisasi elit pedagang.

\section{DAFTAR PUSTAKA}

Andreas Yuniman Tjandra dan Marinus

Wahjudi. 2006. Analisa

Perkembangan Pasar Tradisional

Studi Komparatif Terhadap

Pengguna Ruang Komersial di

Pasar Atum, Pasar Turi, dan Pasar

Wonokromo. URL:

www.bibsonomy.org.

Ayuningsasi, A.K dan Mirah.P.P. (2013).

Efektivitas dan Dampak Program Revitalisasi Pasar Tradisional di

Pasar Agung Peninjoan. Jurnal Ekonomi Pembangunan.

Campbell, R. McConnell and Stanley L. Brue. 1990. Economics: Principles, Problems and Policies. McGrawHill Publishing Company.

Danisworo, Muhammad dan Widjaja Martokusumo. 2000. Revitalisasi

Kawasan Kota Sebuah Catatan dalam Pengembangan dan

Pemanfaatan Kawasan Kota.

Jakarta: Urban and Regional

Development Institute.

URL:http://www.urdi. Ayuningsasi, A.K dan Mirah.P.P. (2013). Efektivitas dan Dampak Program Revitalisasi Pasar Tradisional di Pasar Agung Peninjoan. Jurnal Ekonomi Pembangunan.

Ma'ruf, Handri. (2005).Unsur-unsur Retail Marketing Mix.

Nurjanah, Siti. 2016. Kerangka Acuan Kegiatan Kajian Revitalisasi Pasar Pleret pada KegiataImplementasi Pengembangan Ekonomi Daerah, Bantul. BAPPEDA. 
Prihandana, Ramalis Subandi. (2002).

Redefining the Pasar: Trading

Enterprise, Livelihood, Networks,

and Urban Governance.

Academisch Proefschrift. Vrije

Universiteit, Amsterdam.

Sitompul, Ulyses Leon Hardo. (2012).

Evaluasi Kebijakan Dan Program

Pengembangan Pasar Tradisional

Direktorat Jenderal Perdagangan

Dalam Negeri. Tesis. Program

Magister Studi Pembangunan,

Sekolah Arsitektur, Perencanaan,

dan Pengembangan Kebijakan,

Institut Teknologi Bandung.

Stanton, William J. 2006. Prinsip

Pemasaran, Jilid I (Edisi Ketujuh).

Erlangga: Jakarta. 